\title{
Authoritarian Populist Opinion in Europe
}

\author{
David Sanders* and Joe Twyman** \\ * Department of Government, Universitty of Essex \\ ** YouGov.com
}

March 2017

\begin{abstract}
The paper extends work done on authoritarian populism (AP) in the UK to 11 other European countries: France, Germany, Sweden, Denmark, Finland, Poland, Italy, Spain, Romania, Lithuania, and Holland. Representative sample surveys with a common set of questions were conducted in each of these countries and in the UK in November 2016. The paper shows that authoritarian populist attitudes (anti-immigrant, anti-EU, anti-Human Rights and pro a robust foreign policy) form a single AP factor or scale in ten of the twelve countries surveyed (the two exceptions are Romania and Lithuania). Across these ten countries the sources of AP attitudes are also very similar, with particularly strong effects being observed for the perceived cultural consequences of immigration. The paper uses cluster analysis to show that authoritarian populism is not an exclusively right-wing mindset among European mass publics. Analysis of voting data shows that the reservoir of support for authoritarian populist parties is much larger than either the current electoral strength of such parties or the proportion of the population that intends to vote for them at the next general election would suggest.
\end{abstract}

Keywords: anti-immigration; anti-human rights; Euroscepticism; left-right ideology; vote intention 
The election of Donald Trump in the US and the rise of support for populist parties in Europe have prompted widespread journalistic and academic speculation about the character and strength of populist opinion across the western world. Such opinion constitutes a reservoir of potential support for populist movements that seek to make electoral capital at the expense of established, 'mainstream' political parties. Recent research in the UK has shown that a cluster of attitudes that can reasonably be described as Authoritarian Populist - centring on opposition to immigration, cynicism about human rights, disapproval of the EU, support for a robust defence and foreign policy, and a right-wing ideology - form a single factor that underpins a range of other political preferences (Sanders, Scotto and Reifler, 2016). This paper extends the work done on authoritarian populism (AP) in the UK to 11 other European countries: France, Germany, Sweden, Denmark, Finland, Poland, Italy, Spain, Romania, Lithuania, and Holland. Representative sample surveys with a common set of questions were conducted in each of these countries and in the UK in November 2016.

Part 1 of the paper presents a series of factor and scaling models that show that authoritarian populist attitudes form a single AP factor or scale in ten of the twelve countries surveyed (the two exceptions are Romania and Lithuania). Part 2 shows that across these ten countries the sources of AP attitudes are also very similar, with particularly strong effects being observed for the perceived cultural consequences of immigration. Part 3 relaxes the assumption that authoritarian populism is an exclusively right-wing mindset among European mass publics. It conducts a series of country-bycountry cluster analyses based on the component measures of our authoritarian populist scale, which enable us to identify the main 'political tribes' in each of our twelve countries. They also allow us to differentiate between left-wing and right-wing authoritarian populists, and thus to estimate the respective sizes of the AP support reservoir in each of our sampled countries. Part 4 presents the simple relationship between 'political tribe' membership and voting intention as indicated in our surveys. The results show that the reservoir of support for authoritarian populist parties is much larger than either the current electoral strength of such parties or the proportion of the population that intends to vote for them at the next general election would suggest.

\section{Measuring Authoritarian Populist Opinion in $10 \mathrm{EU}$ countries}

Representative sample surveys were conducted by internet in $12 \mathrm{EU}$ countries in November 2016. Just over one thousand respondents were interviewed in each country, though the sample was slightly larger in the UK ( $\mathrm{N}=1711)$. A multiwave panel survey conducted between 2011 and 2015 had provided evidence that in the UK there is a distinct constellation of attitudes UK that form a single scale which can best described as authoritarian populist. In the surveys conducted in November 2016 we wished to establish the extent to which similar constellations might be observed in other European countries.

Table 1 outlines the eight items we used to measure authoritarian populist dispositions. These comprised: two indicators of attitudes towards immigration (the number of negative emotions associated with immigration and the belief that immigration from outside the EU is a bad thing); two indicators of anti-EU attitudes (disapproval of the EU and distrust of EU institutions); two indicators of respondents' national orientations (the conviction that the respondent's country should pursue a 'strong and tough foreign policy' and the belief that patriotism is important); a single indicator of cynicism about Human Rights (agreement with the proposition that 'People who talk about protecting human rights are mainly interested in protecting the rights of criminals, not those of their 
victims'); and a single measure of ideological position (the respondent's self-placement on an 11point left-right ideological scale). The first seven rows of the table indicate the percentage of respondents who take an authoritarian populist position on each of the indicators shown. Thus, for example, $63 \%$ of all respondents expressed at least one negative emotion about immigration to their respective countries, with the lowest level being reported in Spain (53\%) and the highest in Poland (75\%). Similarly, 36\% of all respondents expressed cynicism about Human Rights, with the lowest level being observed in Sweden (27\%) and the highest in Lithuania and Romania (45\%). The final row of the table shows the mean score on a 0-10 left-right self-placement scale. The mean across all 12 countries is slightly right of centre (5.2), with Spanish respondents on average being the most leftwing (mean score 4.4) and French respondents the most right-wing (5.5).

Table 2 presents the results of a series of exploratory factor analyses and alpha-scaling models that test the proposition that the eight authoritarian populist indicators shown in Table 1 form a single factor or scale. The results are reported for each country separately. In each of the factor models, we expect all the component indicators to load relatively highly on the first factor (the only factor loadings reported) and that the eigenvalues of the first factor will be substantially larger than the equivalent value for the second factor (since such differences reflect the relative importance of the first factor). In the alpha-scaling models, we expect alpha values either close to or greater than a=.7, since this is generally regarded as an indication that the measured items form a single scale.

In ten of the twelve countries, the results broadly conform to this expected pattern. In the UK, for example, all of the component variables load above .5 on the first factor and there is a very large difference between the eigenvalues of the first factor (3.55) and the second factor (0.16). The alpha scale coefficient in the UK model $(0.84)$ is well above the 0.7 threshold. The models produce similarly positive results in France, Germany, Sweden, Denmark, Finand, Poland and the Netherlands. In Italy and Spain, the model fits are less good, though still reasonably close to expectations. In Italy, the position is complicated by the fact that ideological self-placement loads negatively on the first factor, suggesting that authoritarian populist attitudes in that country may be associated more with the political left than with the political right. In Spain, the negative coefficents on the two EU variables suggest that authoritarian populist attitudes tend to be associated with support for rather than disapproval of the EU. Finally, in the Lithuania and Romania models, the models look very weak indeed. Both factor models produce a series of very low loadings on the first factor, and the eigenvalues for the first factor are both below unity - an indication that the first factor explains relatively little of the overall variance in the component indicators. By the same token, the scaling models produce alpha coefficients well below the 0.7 threshold ( 0.37 for Romania; 0.36 for Lithuania). The final column of Table 2 reports the results of factor and alpha-scaling models conducted across the ten countries, excluding Lithuania and Romania. These results strongly meet expectations: averaged across all ten countries, all the component indicators load positively on the first factor; the first factor eigenvalue significantly exceeds that for the second factor; and the alpha coefficient meets the $a=0.7$ threshold.

The results reported in Table 2 clearly support the notion that in the majority of countries examined, there is a set of political attitudes that constitute a distinctive mindset, which we wish to characterise as authoritarian populist. Although there are one or two anomalies that we return to in section 3 below, we would argue that this constellation of attitudes - anti-immigrant, anti-Human Rights, anti-EU, supportive of a strong nation state, and (generally) ideologically right-wing - 
represents an important dimension of contemporary mass political thinking. In the next section, we explore the individual- and system-level sources of this mindset. In this exercise our purpose is twofold: (1) to validate our authoritarian populist scale measure by showing that it correlates more or less as predicted with variables that $a$ priori theorising suggests should influence it; and (2) to provide a preliminary causal account of the origins of authoritarian populist attitudes.

\section{Exploring the sources of Authoritarian Populist attitudes in $10 \mathrm{EU}$ countries}

There are innumberable hypotheses that could be posited to explain why individuals vary in their degree of commitment to authoritarian populist ideas. ${ }^{1}$ Here, we concentrate on a limited set of propositions that our (limited) data enable us to test across the 10 countries where AP attitudes, as shown in Table 2, clearly form a single scale.

We explore seven sets of hypotheses. The first relates to why so many people across Europe appear to be concerned about immigration. One possible reason is that they believe immigration either has had or will have an adverse effect on the community in which they live, making it feel less like the 'home' in which they grew up. This belief does not necessarily reflect the objective size of the local or national immigrant community, but it can have important consequences for the development of an authoritarian populist mindset. We operationalize this notion by assessing the extent to which individuals agree with the statement that 'There are so many foreigners round here that it doesn't feel like home any more'. We hypothesise that agreement will be positively associated with AP attitudes regardless of objective national levels of immigration. A second hypothesis is that AP attitudes are more likely to prevail among those who feel that economic conditions have worsened in the recent past. We measure this feeling, admittedly imperfectly, by looking at people's assessments of whether they think their country's economic circumstances have worsened or improved over the past year. Our third proposition relates to the effects of national versus European identity. We hypothesise that individuals who have an exclusively national identity are more likely to believe in the need to preserve the intergrity and character of the nation-state and hence are more likey to hold more authoritarian populist views.

A fourth hypothesis concerns 'negative valence' - the idea that the incumbent governing party or parties is failing effectively to handle the most important problems facing the country. Individuals who believe that the government is failing to deliver on multiple policy fronts are more likely to develop a rejectionist, AP mindset. We measure valence assessments across seven policy domains (housing, education, immigration, the economy in general, defence, crime and unemployment) and expect our composite index to have a negative effect on our authoritarian populism scale. Our fifth hypothesis relates to the possible role of 'traditional social values'. Since authoritarian populism is often seen as a regressive mindset that favours the re-establishment of a past (and sometimes mythical) political order, it follows that those who favour traditional social values will also tend to hold authoritarian populist views. We use two indicators of such values: agreement (a) with the idea that children should be obedient and respectful towards established authority and (b) with the idea that men and women should pursue very different gender roles in the home and the workplace. We

\footnotetext{
${ }^{1}$ There is an extensive literature on populism that we draw on indirectly to generate these hypotheses. Our hypotheses are derived inter alia from Altmeyer (1981); Barnett (1982); Dix (1985); Ford and Goodwin (2014); Hall, Stewart and Jacques (1983); Jessop et al (1984); Jessop (2016); Jones (2007); Mudde (2004); Scase (1980); Stenner (2005); Wodak et al (2013).
} 
expect these ideas to be positively associated with AP attitudes. A sixth set of explanatory variables relates to issue salience. Here, we hypothesise that AP attitudes should be most prevalent among those who regard immigration or terrorism as the most important issue facing the country; and that they should be least prevalent among those who believe that the most important issue is the gap between rich and poor. Finally, we include controls for three key demographics variables: age, gender and education. Given previous findings on voting support for populist parties, we expect AP attitudes to be associated positively with age and being male, and negatively with education.

Our authoritarian populism dependent variable (APscale) is constructed separately for each country from alpha scale models based on the variables shown in Table 1. Our country-by-country model specification is:

APscale $=a+b_{1}$ NotHome $+b_{2}$ EconomicRetrospections $+b_{3}$ Nationalldentity $+b_{4}$ Valence $+b_{5}$ Obedient $+b_{6}$ DifferentRoles $+b_{7}$ MIP-Immigration $+b_{8}$ MIP-Terror $+b_{9}$ MIP-Gap $+\Sigma \varepsilon_{1}$

where all predictor variable terms are as defined in Table 3, MIP signifies Most Important Problem, and $\Sigma \varepsilon_{1}$ is a random error term. We also estimate a pooled 10-country model, which adds two further, objective country-level control variables: the percentage of the population who were born outside the country as at January 2015 (\%Foreign) and average percentage change in GDP 20052015 (GDPchange). The distributions of these variables are reported in Annex 1. Our pooled model specification is

APscale $=a+b_{1}$ NotHome $+b_{2}$ EconomicRetrospections $+b_{3}$ Nationalldentity $+b_{4}$ Valence

$+b_{5}$ Obedient $+b_{6}$ DifferentRoles $+b_{7}$ MIP-Immigration $+b_{8}$ MIP-Terror $+b_{9}$ MIP-Gap

$+\mathrm{b} 10 \%$ Foreign $+\mathrm{b} 11$ GDPchange $+\Sigma \varepsilon_{1}$

Table 4 estimates [1] for each of the ten countries where AP attitudes form a single scale. Since APscale is a normally distributed interval-level measure, estimation is by OLS. The final column of Table 4 estimates [2], using (country-)clustered regression with robust standard errors. As the results show, the models are all reasonably well-determined. Corrected $R^{2}$ is a modest 0.30 in the Poland model, though this is by no means unusual with individual-level data. For the remaining countries, $R^{2}$ is always well above 0.40 and in the UK, France and Sweden it exceeds 0.60 . The strongest support ofr hypotheses in terms of coefficient signs and significance levels is in the UK. All but three of the independent variables are significant and correctly signed. The only exceptions are education (which is non-significant) and EconomicRetrospections and Valence assessments (which both have significant positive rather than negative effects). For most of the remaining countries in Table 4 the results are broadly similar, with most predictors significant and correctly signed - though inevitably, as in the UK model, there are a small number of coefficients that do not match expectations. The 10-country pooled model is reported in the extreme right-hand column of the table. The $R^{2}$ of 0.48 indicates that the model is well-determined. Of the individual-level coefficients, most are significant and correctly signed though non-significant effects are observed for EconomicRetrospections, Valence assessments and the priorisation of the Rich/Poor gap as the most important problem facing the country. Both of the country-level variables also fail to achieve significance, suggesting that neither objective economic performance nor the objective size of the immigrant population have direct effects on authoritarian populist attitudes. 
The overall coefficient pattern in Table 4 is summarised in Table 5. A positive sign (+) denotes a significant positive estimated effect from Table 4; a negative sign (-) a significant negative effect; and a zero no effect. The table also indicates the predicted effect based on our seven sets of hypotheses. Looking across the rows enables us to assess the number and types of effect that appear to operate in the different countries examined. Thus, for example, the most correctlypredicted effects were evident in France and Sweden (both 10/12 effects correctly predicted) and the least in Poland (6/10 correct) and in Spain (only 4/10 correct). Looking down the columns tells us which predictor variables most consistently had effects in different countries. Here, the consistent, correctly signed effects we observe (in nine out of our ten countries) are those for gender (men are more likely to hold AP views), for the sense that 'it doesn't feel like home round here any more', for an exclusively national identity, and for the prioritising of immigration as the Most Important Problem facing the country. Slightly less pervasive but still widespread effects are also observed for traditional social values (particularly in relation to the need for children to be obedient and to repsect authority) and for the prioritising of the gap between rich and poor as the MIP. These may seem 'obvious' findings - they are - but the fact that the models consistently show these effects across different countries adds credence to our claim that our measure of authoritarian populist attitudes is indeed measuring something real and important.

\section{Europe's emerging political tribes: evidence from Cluster Analyses}

The analysis we have conducted so far treats authoritarian populism as a single, continous scale on which any individual can be located. The evidence presented in Tables 4 and 5 shows that individuals' positions on this scale can be plausibly explained by a number of different individuallevel factors which seem to operate across our ten EU countries. Yet, as we have also seen, there are country-by-country variations in the sizes, signs and significance levels of the different effect coefficients. In addition, as we saw when we discussed factor models earlier, in some countries, leftright ideological self-placement has a somewhat ambiguous correlation with the other components of the authoritarian populist mindset. This begs the question as to whether we should perhaps be looking for the possible existence of distinct left-leaning and right-leaning populist sentient in different countries. One obvious vehicle for such an exploration is cluster analysis. This technique looks for distinct groupings of individuals (that is, who register similar scores) on a given set of characteristics. In this case, the characteristics are the eight component indicators of authoritarian populism that we listed in Table 1. Given that we know (a) from Table 2 that the intercorrelations among the eight components vary across countries and (b) from Table 4 that the sources of AP attitudes also vary across countries, we use separate country-specific cluster analyses to identify the different clusterings or 'political tribes' that characterise each of our ten countries.

Table 6 provides an illustrative cluster analysis for the UK. We estimate 2-, 3-, 4- and 5-cluster models. It would be possible to estimate more clusters or groupings of individual respondents - as we do for some countries as reported below - but we stick at 5 clusters for the UK because with a 5 cluster solution one of the clusters contains only $3 \%$ of respondents. Our operating rule is that if a cluster contains 5 or less percent of the sampled population, it is unrealistic to describe that grouping as a 'political tribe'. We realise this is an arbitrary figure - but unless we had employed some decision rule, we could have estimated an ever-more differentiated set of groupings (which would also have been increasingly unstable, given that our effective sample size for most of our 
analysed countries is under $\mathrm{N}=1000$ ) that would probably have revealed very little about the 'actual' political tribes in each country.

The first, 2-cluster, solution shown in Table 6 shows that Cluster 2 respondents score higher on each of the eight AP indicators than do Cluster 1 respondents. However, the numerical differences between the two groups, though statistically significant, are not not particularly large - for example, the Cluster 1 mean for Negative Immigration Emotions is 0.84, compared with a igure of 1.10 for Cluster 2. Moreover, if we were to describe all Cluster 2 respondents as Authoritarian Populists, we would not only be inferring that fully $64 \%$ of the UK electorate were AP or AP-incliners but doing so on the basis of relatively small differences in mean scores across the eight component items.

The 3-cluster solution differentiates between two groupings previously within Cluster 1 of the 2cluster solution. In the 3-cluster model, Cluster 2 respondents are clearly left-wing (mean score 3.93) but they are also strongly anti-immigrant (Negative Emotions mean score=2.20; Opposed to non-EU Immigration score of 3.99), anti-EU (disapproval 4.25; anti-EU Institutions 2.86), supportive of the strong nation-state (Strong Foreign Policy .43; Patriotism Important 4.10), and critical of Human Rights (mean 3.78). In short, these Cluster 2 respondents, who represent $14 \%$ of the electorate, exhibit most of the key characteristics of authoritarian populists, even though they are leftwing. Bizarrely, they look more authoritarian populist than the $64 \%$ of respondents now in Cluster 3 (exactly the same group who were in Cluster 2 in the 2-cluster model) who also classify themselves, on average, as more right-wing.

This is where the 4-cluster solution comes in. This solution distinguishes between two groups inside Cluster 3 of the 3 -cluster solution. In Cluster 3 of the 4-cluster model, there is a clear centre-right group (mean ideology score $=5.39$ ) which is broadly sympathetic to immigration (mean Negative Emotions=.43), pro-EU (mean EU disapproval=2.08) moderate on foreign policy (mean score=.19), and relatively uncritical on Human Rights (mean score $=2.65$ ). This group is very different from the more distinctly right-wing authoritarian populists indicated in Cluster 4 - who on average score noticeably higher on all eight of the component measures than the 'social liberals' in Cluster 3.

The final segment of Table 6, for completeness, reports the results of a 5-cluster solution. The key difference from the 4-cluster solution is that the $14 \%$ of left-wing APs in that model are now divided into two groups which look very similar across most of the eight components, though they do differ a little in terms of Immigration Emotions and antipathy towards Human Rights. However, the Cluster 3 respondents in the 5 -cluster solution constitute under $3 \%$ of our sample and thus fall below our self-imposed inferential threshold of the defintition of a distinct tribe or grouping. We conclude that the 4-cluster solution shown in Table 6 makes the most sense in terms of identifying the UK's most important political tribes. As we indicate in the table, on the basis of the 4-cluster solution, we would characterise members of Cluster 1 as Left Liberals ( $23 \%$ of the electorate), Cluster 2 as Left Authoritarian Populists (14\%), Cluster 3 as Centre-Right Liberals (30\%), and Cluster 4 as Right-wing Authoritarian Populists (34\%). In short, in the UK at least, our AP distinction cuts across traditional notions of left and right. A substantial proportion of the population (around $48 \%$ on our estimate) holding broadly AP attitudes, drawn from both right (34\%) and left (14\%) of the ideological spectrum.

We repeated the analysis shown in Table 6 for each of the remaining nine countries in our reduced 10-country sample. The detailed results are reported in Annex 2 but Table 7 shows the headline 
results. The clusters reported represent our best estimates of the contemporary political tribes in each of our ten countries. They also represent our conclusions about the character and size of the different authoritarian populist groupings in each country. In France, for example, we estimate the size of the total AP population at $66 \%$, divided into $25 \%$ who place themselves clearly on the ideological right and $41 \%$ who place themselves on the centre-right. In Holland, in contrast, we observe only 30\%, divided equally between right APs(15\%) and centre-left APs (also 15\%). Figure 1 summarises the overall AP pattern across all ten countries. In our view, these AP groupings (of admittedly different sorts) represent the support reservoirs for authoritarian populist parties in future elections in their respective countries.

\section{So what? Political Tribe Membership and Voting Intentions}

We suggested above that the authoritarian populist mindset is more prevalent among European mass publics than current levels of voting for right-wing populist parties would imply. Figure 2 compares the levels of AP opinion across our ten countries with the levels of populist party voting in their most recent general elections. As the figure shows, the size of the AP reservoir in each country is clearly greater than the actual proportion of the population that voted right-wing populist. Given that there are many other reasons why people vote the way they do - among them party identifications, leader affect, issue salience assessments and economic evaluations - this is not surprising. Significantly, the same pattern is also evident if we compare the size of the AP 'tribe(s)' in each country with the intention to vote for a right-wing populist party in the next general election, as in Figure 3. As the figure indicates, the extent of AP sentiment is consistently greater than the proportion of voters intending to vote for a populist party.

The relationship between authoritarian populist attitudes and party preferences is obviously more complicated thn the simpe observation that there are more authoritarian populists than right-wing populist voters. In order to make cross-national comparisons feasible, we characteris the parties in each of our ten countries according to the classification provided by Wolfram Nordsieck at http://www.parties-and-elections.eu/countries.html. We condense the party groupings summarised by Nordsieck into five 'party family' categories as follows:

[1] Far left, including communist and radical left parties

[2] Centre Left, including social democracy, green left and nationalist left parties

[3] Centre, including liberal and social liberal parties

[4] Centre Right, including Christian democrat, conservative, centre-right liberal parties

[5] Right-wing Populist, including Eurosceptic, national conservative parties

Thus, in the UK for example, the Far Left category [1] is empty - though this may change in the future as the Labour left under Jeremy Corbyn consolidates its position within the party; category [2] contains Labour, the Scottish Nationalists, Plaid Cymru and the Greens; category [3] contains the Liberal Democrats; category [4] the Conservative; and category [5] UKIP and the British National Party. The allocations of parties to categories in the other nine countries are outlined in Annex 3.

Table 8 reports the simple relationship across our ten countries between party-family vote intention and whether or a respondent belongs to an authoritarian populist 'tribe'. The detailed countryspecific distributions are reported in Annex 4. Annex 5 presents a simple ordered logistic model of the Party-Family variable, which shows that the strong bivariate relationship between vote intention and AP tribe persists in the face of multivariate controls. 
The table differentiates between right-wing and left-wing AP tribes, the latter ( $8 \%$ of respondents) being much smaller than the former (37\%). It is clear from the table that there is a fairly strong, though by no means invariant, relationship between vote intention and tribe. Among the non-APs, support is distributed predominantly among the four non-Populist party groupings, with the Centreleft, Centre and Centre-Right together attracting some $81 \%$ of the non-AP vote. Among the left-APs, the votes are distributed across the five party groupings, though there is a clear tendency for them, despite their leftist ideological orientations, to vote for either Centre-right (28\%) or Right-wing Populist parties (25\%). Right-wing APs do not uniformly support right-wing parties. Roughly one third of them (34\%) support either Left, Centre-left or Centre parties, thought the other two-thirds clearly intend to vote either Centre-right or Populist right.

The key figures in the RightAP column, however, are the $31 \%$ who support Centre-Right parties and and the $35 \%$ who intend to vote for Right-wing Populist parties. At present, Centre-Right parties are just as successful at attracting the support of right-wing populist voters as are the right-wing populist parties themselves. If this pattern continues, then right-wing populism in Europe may not progress much further beyond its current levels in the coming years. But there is a real risk here. On the one hand, Centre-right parties may feel that in order to meet voter concerns about immigration and the negative economic consequences of globalisation they need to transmute themselves in antiimmigrant, protectionist Right-wing populist parties in order to survive electorally. On the other hand, if Centre-right parties fail properly to respond to widespread voter concerns about these issues, they will find themselves undercut by the growing attraction of right-wing populist parties that will undoubtedly seek to mobilise as much of their potential authoritarian tribal support base as they possibly can. The only real protection against the rising tide of authoritarian populist sentiment among European voters is for the entire liberal political establishment (from the Centre-left to the Centre-right) to start to talk openly and honestly about the long-term social costs of immigration and economic globalisation. It is simply not good enough for liberals to emphasise the economic benefits of immigration and to castigate voters who are seduced by populist solutions with labels such as 'ignorant', 'neo-fascist' or 'gullible'. The concerns articulated by the members of the authoritarian populist tribe that we have outlined here are real. They need to heard and addressed rather than condemned. We are convinced that if they are ignored, the extensive authoritarian populist sentiment we have described risks being mobilised increasingly by right-wing populist parties whose simplistic solutions to complex problems risk serious social, economic and political damage.

\section{Summary and Conclusions}

'Populism' is often used imprecisely to describe anti-establishment political movements which propose simple solutions to complicated problems and which advocate popular policies that liberals find uncomfortable. We have tried to avoid any such usage here. Rather, we have described what we characterise as authoritarian populist sentiment among European mass publics as a mindset that combines a preference for strong national foreign policies with opposition to immigration, antiEuropeanism, an antipathy to the liberal human rights agenda and a right-wing political orientation. We found evidence of this mindset in ten of the twelve countries that we surveyed in November 2016. In those ten countries, factor-analytic and alpha-scale models indicated the existence of a statistically coherent constellation of authoritarian attitudes. We showed in simple regression models that across all ten countries, individuals' positions on an authoritarian populism scale could 
be predicted reasonably satisfactorily by a series of theoretically-informed predictor variables. In particular we found that the perceived community consequences of immigration, strong national identity and the prioritisation of immigration as an issue all had strong effects on AP orientations.

Cluster analysis enabled us to explore the potential size of the AP population in each of our ten countries where we observed a clear AP scale. Significantly, this analysis allowed us to differentiate between the right- and left-wing AP 'tribes' which exist in some countries. In our sample, there are sizeable left-AP groups in the UK, Finland, Poland, Italy and the Netherlands. There is a also a large Centre-right AP group in France. Our analysis of the relationship between AP attitudes and vote intention shows that at the moment, centre-right parties across Europe can expect to garner as much support from authoritarian populist voters as can right-wing populist parties. Our supposition, which we hope to have justified in the analysis here, is that members of the authoritarian populist tribes in different countries represent a potential support reservoir that may be attracted to populist parties in the future. Donald Trump's success in the US appears to show the power of an intelligently-targeted social media campaign to mobilise support among those who adhere to an authoritarian populist mindset. It is likely that right wing populist parties in Europe will be seeking to emulate these efforts in the years ahead. Those who would resist the rising tide of populism in Europe should start taking action now, aimed at persuading those members of the AP tribe who have not yet succumbed to the electoral atractions of right-wing populism not to switch their votes from their current, Centre-right intentions. 


\section{References}

Altemeyer, R. 1981. Right-wing authoritarianism. Winnipeg: University of Manitoba Press.

Barnett, Anthony. 1982. Iron Britannia, New Left Review 134: 5-96.

Bowler, Sean and Todd Donovan, 2002. Democracy, institutions, and influence on citizen influence on government. British Journal of Political Science 37 (2): 371-390.

Dix, Robert H. 1985. Populism: Authoritarian and Democratic. Latin American Research Review, 20 (2): 29-52

Ford, Robert and Matthew Goodwin. 2014. Revolt on the Right: Explaining Support for the Radical Right in Britain. London: Routledge

Haidt, J. 2016. "When and Why Nationalism Beats Globalism". The American Interest.

http://www.the-american-interest.com/2016/07/10/when-and-why-nationalism-beats-globalism/ Hall, Stuart and Jacques (eds), 1983. The Politics of Thatcherism. London: Lawrence and Wishart Jessop, Bob, Kevin Bonnett, Simon Bromley and Tom Ling. 1984. Authoritarian Populism, Two Nations, and Thatcherism, New Left Review, 147: 32-60.

Jessop, Bob. .2016. The organic crisis of the British state: Putting Brexit in its place. Globalizations 14:133-141

Jones, Erik. 2007. Populism in Europe. SAIS Review of International Affairs, 27 (1): 37-47

Mudde, C. 2004. The Populist Zeitgeist. Government and Opposition 39:542-563.

Sanders, David, Tom Scotto and Jason Reifler. 2016. The Consequences of Authoritarian Populism In Britain. Available at http://repository.essex.ac.uk/18211/Scase, Richard (ed). 1980. The State in Western Europe. London: St Martin's Press.

Stenner, K. 2005. The authoritarian dynamic. 1st ed. New York: Cambridge University Press.

Wodak, Ruth, Majid KhosraviNik and Brigitte Mral (eds), 2013. Right-Wing Populism in Europe:

Politics and Discourse. London: Bloomsbury Academic 
Figure 1: Levels Right-wing and Left-wing Authoritarian Populism in Ten European Countries

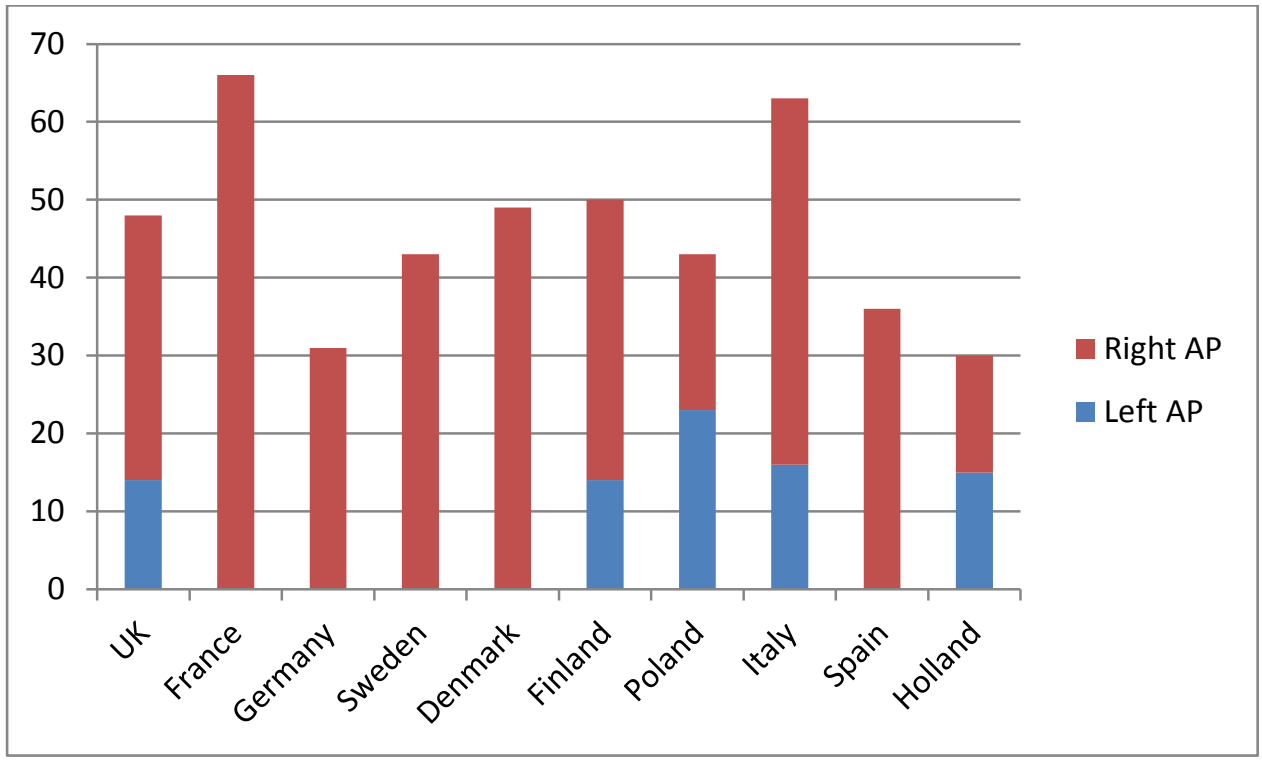

Cluster-analysis-derived estimates of the percentages of the total electorate with an Authoritarian Populist (AP) mindset

Figure 2: Right-wing Populist Voting in most recent General election in ten European Countries

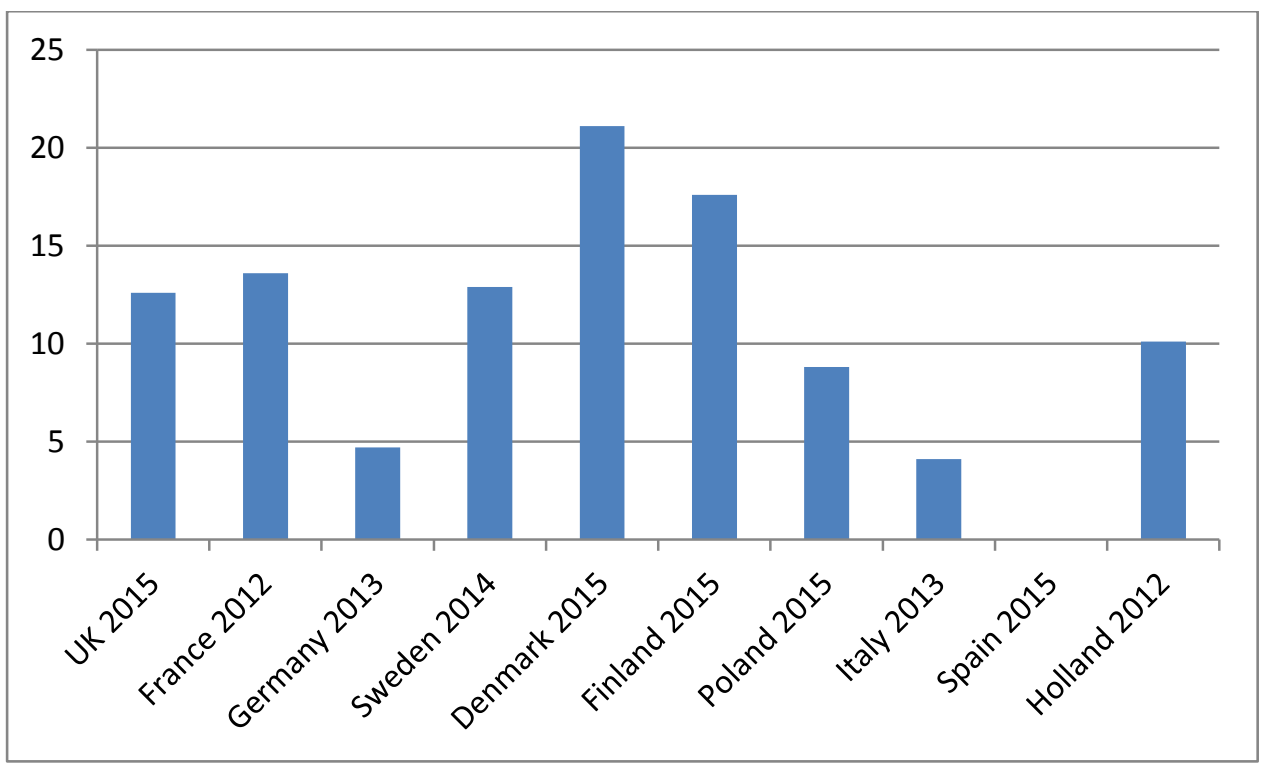

Percentage of votes cast for parties described by Wolfram Nordsieck party as right-wing populist, right-wing nationalist or Eurosceptic/National Conservative. Source: http://www.parties-andelections.eu/countries.html 
Figure 3: Right-wing Populist Vote Intention and the size of the Authoritarian Populist 'tribe' in Ten European Countries

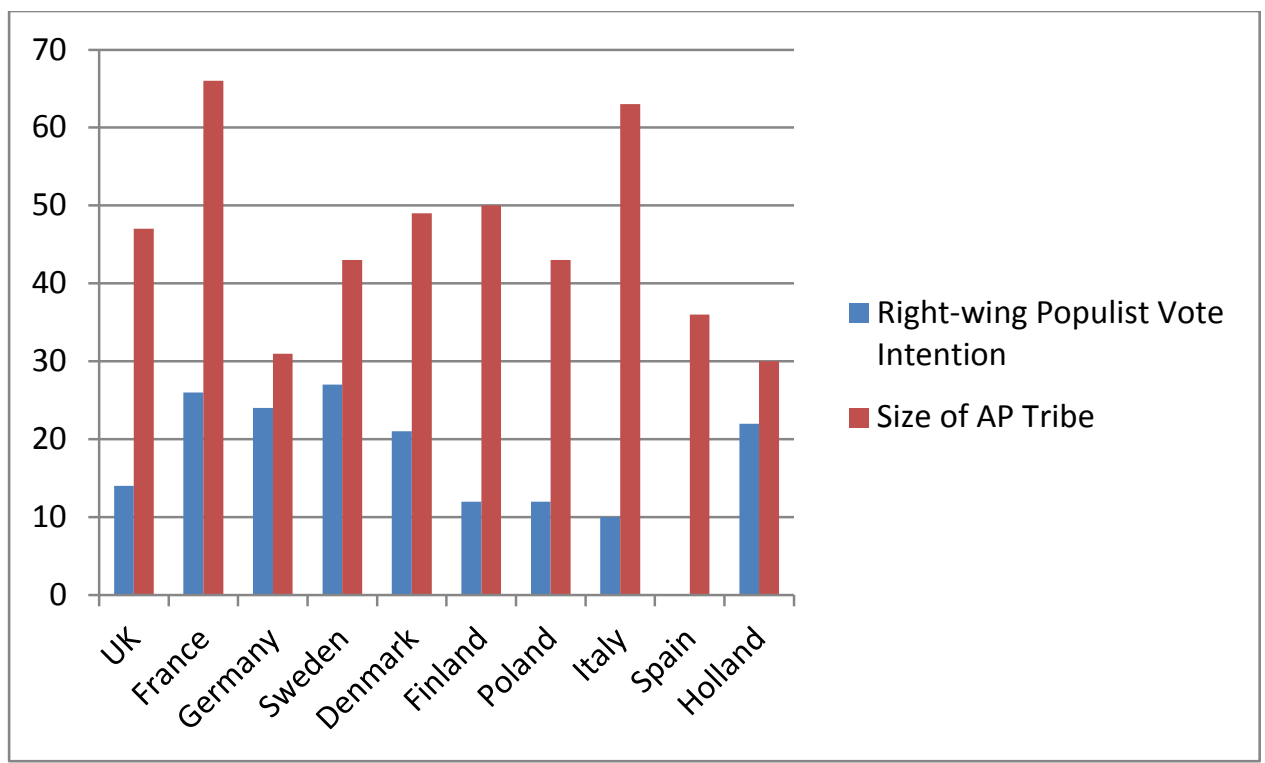


Table 1: Eight Indicators of Authoritarian Populism; Variable Definitions and Summary Measures (Mean scores in parentheses)

\begin{tabular}{|c|c|c|c|c|c|c|c|c|c|c|c|c|c|}
\hline & UK & France & Germany & Sweden & Denmark & Finland & Poland & Italy & Spain & Romania & Lithuania & Holland & All \\
\hline $\begin{array}{l}\text { \% Displaying Negative } \\
\text { Emotions on Immigration }\end{array}$ & $\begin{array}{l}57 \\
(1.1)\end{array}$ & $\begin{array}{l}72 \\
(1.3)\end{array}$ & $\begin{array}{l}60 \\
(1.1)\end{array}$ & $\begin{array}{l}66 \\
(1.5)\end{array}$ & $\begin{array}{l}63 \\
(1.6)\end{array}$ & $\begin{array}{l}68 \\
(1.5)\end{array}$ & $\begin{array}{l}75 \\
(1.4)\end{array}$ & $\begin{array}{l}68 \\
(1.2)\end{array}$ & $\begin{array}{l}53 \\
(0.8)\end{array}$ & $\begin{array}{l}64 \\
(1.2)\end{array}$ & $\begin{array}{l}60 \\
(1.0)\end{array}$ & $\begin{array}{l}59 \\
(1.1)\end{array}$ & $\begin{array}{l}63 \\
(1.2)\end{array}$ \\
\hline $\begin{array}{l}\text { \% Agree Immigration from } \\
\text { outside EU is a bad thing }\end{array}$ & $\begin{array}{l}37 \\
(3.1)\end{array}$ & $\begin{array}{l}54 \\
(3.7)\end{array}$ & $\begin{array}{l}49 \\
(3.5) \\
\end{array}$ & $\begin{array}{l}47 \\
(3.4)\end{array}$ & $\begin{array}{l}56 \\
(3.7)\end{array}$ & $\begin{array}{l}57 \\
(3.7)\end{array}$ & $\begin{array}{l}53 \\
(3.6)\end{array}$ & $\begin{array}{l}52 \\
(3.6)\end{array}$ & $\begin{array}{l}36 \\
(3.2)\end{array}$ & $\begin{array}{l}42 \\
(3.4)\end{array}$ & $\begin{array}{l}52 \\
(3.6)\end{array}$ & $\begin{array}{l}46 \\
(3.5)\end{array}$ & $\begin{array}{l}48 \\
(3.5)\end{array}$ \\
\hline \% Disapprove of EU & $\begin{array}{l}44 \\
(3.0)\end{array}$ & $\begin{array}{l}37 \\
(2.8)\end{array}$ & $\begin{array}{l}26 \\
(2.5) \\
\end{array}$ & $\begin{array}{l}43 \\
(3.1)\end{array}$ & $\begin{array}{l}31 \\
(2.7)\end{array}$ & $\begin{array}{l}28 \\
(2.5)\end{array}$ & $\begin{array}{l}16 \\
(2.0)\end{array}$ & $\begin{array}{l}31 \\
(2.6)\end{array}$ & $\begin{array}{l}15 \\
(2.0)\end{array}$ & $\begin{array}{l}16 \\
(2.2)\end{array}$ & $\begin{array}{l}20 \\
(2.1)\end{array}$ & $\begin{array}{l}34 \\
(2.8)\end{array}$ & $\begin{array}{l}29 \\
(2.6)\end{array}$ \\
\hline \% Distrust EU Institutions & $\begin{array}{l}58 \\
(2.4)\end{array}$ & $\begin{array}{l}58 \\
(2.4)\end{array}$ & $\begin{array}{l}51 \\
(2.3) \\
\end{array}$ & $\begin{array}{l}44 \\
(2.3)\end{array}$ & $\begin{array}{l}40 \\
(2.1)\end{array}$ & $\begin{array}{l}43 \\
(2.2)\end{array}$ & $\begin{array}{l}34 \\
(2.0)\end{array}$ & $\begin{array}{l}49 \\
(2.2)\end{array}$ & $\begin{array}{l}42 \\
(2.1)\end{array}$ & $\begin{array}{l}29 \\
(1.9)\end{array}$ & $\begin{array}{l}26 \\
(1.8)\end{array}$ & $\begin{array}{l}53 \\
(2.3)\end{array}$ & $\begin{array}{l}45 \\
(2.2)\end{array}$ \\
\hline $\begin{array}{l}\text { \% Agree Foreign policy } \\
\text { should be strong and tough }\end{array}$ & $\begin{array}{l}31 \\
(.31)\end{array}$ & $\begin{array}{l}42 \\
(.42)\end{array}$ & $\begin{array}{l}11 \\
(.11) \\
\end{array}$ & $\begin{array}{l}17 \\
(.17)\end{array}$ & $\begin{array}{l}17 \\
(.17)\end{array}$ & $\begin{array}{l}21 \\
(.21)\end{array}$ & $\begin{array}{l}30 \\
(.30)\end{array}$ & $\begin{array}{l}34 \\
(.34)\end{array}$ & $\begin{array}{l}22 \\
(.22)\end{array}$ & $\begin{array}{l}26 \\
(.26)\end{array}$ & $\begin{array}{l}20 \\
(.20)\end{array}$ & $\begin{array}{l}27 \\
(.27)\end{array}$ & $\begin{array}{l}25 \\
(.25)\end{array}$ \\
\hline $\begin{array}{l}\% \text { Agree Patriotism is } \\
\text { important }\end{array}$ & $\begin{array}{l}62 \\
(3.7)\end{array}$ & $\begin{array}{l}71 \\
(4.0)\end{array}$ & $\begin{array}{l}43 \\
(3.4)\end{array}$ & $\begin{array}{l}49 \\
(3.4)\end{array}$ & $\begin{array}{l}45 \\
(3.4)\end{array}$ & $\begin{array}{l}65 \\
(3.8)\end{array}$ & $\begin{array}{l}69 \\
(3.9)\end{array}$ & $\begin{array}{l}61 \\
(3.7)\end{array}$ & $\begin{array}{l}49 \\
(3.4)\end{array}$ & $\begin{array}{l}75 \\
(4.1)\end{array}$ & $\begin{array}{l}65 \\
(3.8)\end{array}$ & $\begin{array}{l}43 \\
(3.4)\end{array}$ & $\begin{array}{l}58 \\
(3.7) \\
\end{array}$ \\
\hline$\%$ Critical of Human Rights & $\begin{array}{l}38 \\
(3.0)\end{array}$ & $\begin{array}{l}43 \\
(3.3)\end{array}$ & $\begin{array}{l}30 \\
(3.0)\end{array}$ & $\begin{array}{l}27 \\
(2.8)\end{array}$ & $\begin{array}{l}24 \\
(2.8)\end{array}$ & $\begin{array}{l}36 \\
(3.1)\end{array}$ & $\begin{array}{l}37 \\
(3.2)\end{array}$ & $\begin{array}{l}37 \\
(3.1)\end{array}$ & $\begin{array}{l}33 \\
(3.0)\end{array}$ & $\begin{array}{l}45 \\
(3.4)\end{array}$ & $\begin{array}{l}45 \\
(3.4)\end{array}$ & $\begin{array}{l}29 \\
(3.0)\end{array}$ & $\begin{array}{l}36 \\
(3.1)\end{array}$ \\
\hline $\begin{array}{l}\text { Mean score on 0-10 self- } \\
\text { placement Left-Right scale }\end{array}$ & 5.0 & 5.5 & 4.8 & 5.3 & 5.3 & 5.1 & 5.3 & 5.4 & 4.4 & 5.3 & 5.3 & 5.3 & 5.2 \\
\hline $\mathrm{N}$ of cases & 1711 & 1002 & 1046 & 1008 & 1008 & 1006 & 1016 & 1012 & 1010 & 1012 & 1015 & 1015 & 12860 \\
\hline
\end{tabular}

For individual country models, data weighted by in-country weights. For pooled model, data weighted to equal Ns across countries.

Question wordings and codings were as follows:

Negative Immigration Emotions. Which, if any, of the following words describe your feelings about immigration? (Please tick up to four). Response options: Angry, Happy, Disgusted, Hopeful, Uneasy, Confident, Afraid, Proud. The number of negative emotions (Angry, Disgusted, Uneasy, Afraid) is counted to create a 0-4 index

Immigration is a bad thing. Generally speaking, do you think Immigration from countries outside the EU is a good or bad thing for [COUNTRY]? Response options: A very good thing (coded 1) ; A fairly good thing (coded 2) ; Neither good nor bad (3); A fairly bad thing (coded 4); A very bad thing (coded 5); DK recoded as 3

EU disapproval. Overall, (did) do you strongly approve, approve, disapprove, or strongly disapprove of COUNTRY'S membership of the European Union? Response options: Strongly approve (coded 1); Approve (coded 2); Don't Know (coded 3); Disapprove (coded 4); Strongly Disapprove (coded 5). 
Distrust EU institutions. For each of the following institutions, please say whether you tend to trust it or tend not to trust it: European Commission; European Parliament. Response options: Tend to trust (coded 1); Don't Know (coded 2); Tend not to trust (coded 3).

Foreign policy should be strong and tough. From the list of priorities, please select the one you think is the most important for [Country]: 1 Helping the rest of the world by providing foreign aid and protecting human rights; 2 Solving international problems by working with other nations and working through international organizations; 3 Protecting COUNTRY'S interests by being strong and tough with other nations and maintaining a powerful military; 4 Avoiding involvement with other nations by simply minding our own business in international affairs; 5 None of these; 6 Don't know. Respondents who select option 3 are coded as 1 ; all others are coded as zero.

Patriotism is important. It is important for [country's] people to be patriotic towards [country]. Response Options: Strongly Agree (coded 5); Agree (coded 4); Neither/Don't Know (coded 3); Disagree (coded 2); Strongly Disagree (coded 1).

Critical of Human Rights. To what extent do you agree or disagree with the following statement: People who talk about protecting human rights are mainly interested in protecting the rights of criminals, not those of their victims. Response Options and codings as for Patriotism is important.

Left-Right self-placement. People sometimes use the labels 'left' or 'left wing' and 'right' or 'right wing' to describe political parties, party leaders, and political ideas. Using the 0 to 10 scale below, where the end marked 0 means left and the end marked 10 means right, where would you place yourself on this scale? 
Table 2: Summary of Factor Analyses and Alpha-scaling analyses in 12 EU Countries

\begin{tabular}{|c|c|c|c|c|c|c|c|c|c|c|c|c|c|}
\hline & \multicolumn{13}{|c|}{ Factor 1 Loadings } \\
\hline & UK & France & German & Sweden & Denmk & Finlnd & Poland & Italy & Spain & Roman & Lithua & Holland & Ten* \\
\hline Negative Immigration Emotions & .71 & .67 & .64 & .77 & .69 & .62 & .48 & .61 & .51 & .46 & .38 & .59 & .65 \\
\hline Non-EU Immigration is a bad thing & .67 & .73 & .70 & .81 & .75 & .70 & .53 & .64 & .52 & .43 & .36 & .62 & .67 \\
\hline Disapproval of EU & .76 & .51 & .48 & .59 & .48 & .58 & .55 & .61 & -.24 & .43 & .45 & .64 & .54 \\
\hline Distrust of EU Institutions & .63 & .38 & .44 & .56 & .50 & .57 & .62 & .49 & -.24 & .50 & .50 & .55 & .48 \\
\hline Foreign policy strong and tough & .52 & .45 & .26 & .43 & .39 & .25 & .47 & .36 & .31 & .22 & .07 & .40 & .40 \\
\hline Patriotism is important & .68 & .50 & .51 & .70 & .61 & .39 & .27 & .35 & .59 & .14 & .09 & .47 & .52 \\
\hline Critical of Human Rights & .73 & .61 & .51 & .64 & .60 & .63 & .39 & .49 & .42 & .24 & .39 & .47 & .57 \\
\hline Left-Right self-placement & .60 & .52 & .50 & .48 & .47 & .18 & .44 & -.40 & .53 & -.12 & -.07 & .38 & .37 \\
\hline Factor 1 Eigenvalue & 3.55 & 2.47 & 2.18 & 3.22 & 2.64 & 2.17 & 1.83 & 2.03 & 1.55 & 0.97 & 0.89 & 2.19 & 2.29 \\
\hline Factor 2 Eigenvalue & 0.16 & 0.48 & 0.25 & 0.56 & 0.68 & 0.68 & 0.41 & 0.41 & 0.91 & 0.37 & 0.54 & 0.32 & 0.50 \\
\hline Alpha scale coefficient & 0.84 & 0.70 & 0.72 & 0.79 & 0.73 & 0.66 & 0.62 & 0.66 & 0.59 & 0.37 & 0.36 & 0.70 & 0.70 \\
\hline Mean Alpha scale score (range 0-1) & .45 & .70 & .31 & .49 & .50 & .49 & .41 & .60 & .24 & -- & -- & .33 & .45 \\
\hline $\mathrm{N}$ of cases & 1265 & 815 & 873 & 881 & 911 & 783 & 849 & 815 & 908 & 716 & 723 & 821 & 8921 \\
\hline
\end{tabular}

* Pooled models across ten countries, excluding Romania and Lithuania; no Alpha scale scores for Romania and Lithuania 
Table 3: Independent Variable Definitions and Summary Scores

\begin{tabular}{|c|c|c|c|}
\hline Variable Name & Variable definition & Range & Mean \\
\hline \multicolumn{4}{|c|}{ Demographic Controls } \\
\hline Male & Respondent's sex: male $=1$; female $=0$ & $0-1$ & 0.48 \\
\hline \multicolumn{4}{|c|}{ Cultural and Economic factors } \\
\hline NotHome & $\begin{array}{l}\text { Likert agreement/disagreement scale with 'There are so many foreigners around here that it doesn't feel like home } \\
\text { any more' }\end{array}$ & $1-5$ & 2.90 \\
\hline $\begin{array}{l}\text { Economic } \\
\text { Retrospections }\end{array}$ & $\begin{array}{l}\text { How do you think the COUNTRY economy has changed over the LAST } 12 \text { months? Response option codings: Got a lot } \\
\text { better (5); Got a little better (4); Stayed the same/DK (3); Got a little worse (2); Got a lot worse (1) }\end{array}$ & $1-5$ & 2.62 \\
\hline National Identity & $\begin{array}{l}\text { Do you see yourself as...? Response options: NATIONALITY only; NATIONALITY and European; European and } \\
\text { NATIONALITY; European only; Other; Don't know. NATIONALITY only coded as 1; others as zero. }\end{array}$ & $0-1$ & 0.37 \\
\hline $\begin{array}{l}\text { Valence } \\
\text { Assessments }\end{array}$ & $\begin{array}{l}\text { How well or badly do you think the government is handling the issue of...? Seven issues assessed: housing, education, } \\
\text { immigration, the economy in general, defence, crime and unemployment. For each issue, response options were: } \\
\text { Very Well (coded 5); Fairly well (4); Don't Know (3); Fairly badly (2); Very badly (5). A combined index was calculated } \\
\text { by summing the individual scores on each of the seven items and dividing by } 7 .\end{array}$ & $1-5$ & 2.38 \\
\hline \multicolumn{4}{|c|}{ Traditional Social Values } \\
\hline MIP-Immigration & $\begin{array}{l}\text { Which two of these problems are most important facing [COUNTRY] just now? Respondents specifying 'The level of } \\
\text { immigration' coded 1; not zero }\end{array}$ & $0-1$ & 0.44 \\
\hline MIP-Terror & $\begin{array}{l}\text { Which two of these problems are most important facing [COUNTRY] just now? Respondents specifying 'The threat of } \\
\text { international terrorism or aggression' coded 1; not zero }\end{array}$ & $0-1$ & 0.37 \\
\hline MIP-Gap & $\begin{array}{l}\text { Which two of these problems are most important facing [COUNTRY] just now? Respondents specifying 'The gap } \\
\text { between rich and poor' coded 1; not zero }\end{array}$ & $0-1$ & 0.42 \\
\hline \multicolumn{4}{|c|}{ Country-level controls } \\
\hline \%Foreign & Percentage of non-native born inhabitants of the country 2015 (source Eurostat) & $.7-7$ & 3.20 \\
\hline GDPchange & Annual average percentage change in GDP per capita 2005-2015 (source Eurostat) & $.3-9.6$ & 5.55 \\
\hline
\end{tabular}


Table 4, Part 1: OLS Models of Authoritarian Populism Scale Scores

\begin{tabular}{|c|c|c|c|c|c|c|c|c|c|c|c|c|c|c|c|}
\hline & \multicolumn{3}{|l|}{ UK } & \multicolumn{3}{|c|}{ France } & \multicolumn{3}{|c|}{ Germany } & \multicolumn{3}{|c|}{ Sweden } & \multicolumn{3}{|c|}{ Denmark } \\
\hline & $b$ & st & $p$ & $b$ & st & $p$ & $b$ & st & $p$ & $b$ & st & $p$ & $b$ & st & $p$ \\
\hline \multicolumn{16}{|c|}{ Demographic Controls } \\
\hline Age & .01 & .00 & .00 & .00 & .00 & .06 & .00 & .00 & .01 & .00 & .00 & .00 & .01 & .00 & .00 \\
\hline Male & .12 & .02 & .00 & .09 & .03 & .05 & .12 & .03 & .00 & .17 & .03 & .00 & .11 & .03 & .00 \\
\hline Education & .02 & .02 & .19 & -.01 & .03 & .79 & -.02 & .02 & .32 & .04 & .02 & .07 & .05 & .02 & .02 \\
\hline \multicolumn{16}{|c|}{ Cultural and Economic factors } \\
\hline NoHome & .22 & .01 & .00 & .19 & .01 & .00 & .24 & .01 & .00 & .26 & .01 & .00 & .25 & .02 & .00 \\
\hline EconRetro & .08 & .02 & .00 & -.08 & .02 & .00 & -.01 & .02 & .77 & -.10 & .02 & .00 & -.02 & .02 & .43 \\
\hline Natid & .22 & .03 & .00 & .19 & .03 & .00 & .14 & .03 & .00 & .16 & .03 & .00 & .18 & .03 & .00 \\
\hline Valence & .08 & .02 & .00 & -.23 & .02 & .00 & -.17 & .02 & .00 & -.22 & .02 & .00 & .03 & .02 & .15 \\
\hline \multicolumn{16}{|c|}{ Traditional Social Values } \\
\hline Obedience & .06 & .01 & .00 & .12 & .02 & .00 & .05 & .01 & .00 & .05 & .01 & .00 & .09 & .02 & .00 \\
\hline DiffRole & .07 & .01 & .00 & .01 & .01 & .64 & .02 & .01 & .06 & .03 & .01 & .02 & .03 & .02 & .07 \\
\hline \multicolumn{16}{|c|}{ Issue Salience } \\
\hline MIP-Immig & .42 & .03 & .00 & .28 & .04 & .00 & .20 & .03 & .00 & .14 & .03 & .00 & .36 & .04 & .00 \\
\hline MIP-Terror & .09 & .03 & .00 & .09 & .03 & .01 & .05 & .03 & .10 & .02 & .06 & .77 & .05 & .04 & .21 \\
\hline MIP-Gap & -.12 & .04 & .00 & -.19 & .04 & .00 & -.05 & .03 & .09 & -.14 & .04 & .00 & -.14 & .04 & .00 \\
\hline Constant & .41 & .08 & .00 & 2.08 & .11 & .00 & 1.68 & .12 & .00 & 1.93 & .11 & .00 & .91 & .12 & .00 \\
\hline Ctd R2 & \multicolumn{3}{|l|}{.63} & \multicolumn{3}{|l|}{.62} & \multicolumn{3}{|l|}{.55} & \multicolumn{3}{|l|}{.69} & \multicolumn{3}{|l|}{.54} \\
\hline $\mathrm{N}$ & \multicolumn{3}{|c|}{1711} & \multicolumn{3}{|l|}{1001} & \multicolumn{3}{|l|}{1045} & \multicolumn{3}{|l|}{1016} & \multicolumn{3}{|l|}{1008} \\
\hline
\end{tabular}

$\mathrm{b}=$ coefficient; $\mathrm{st}$ = standard error; $\mathrm{p}=$ probability. For individual country models, data weighted by in-country weights.

For pooled model, data weighted to equal Ns across countries 
Table 4, Part 2: OLS Models of Authoritarian Populism Scale Scores

\begin{tabular}{|c|c|c|c|c|c|c|c|c|c|c|c|c|c|c|c|c|c|c|}
\hline & \multicolumn{3}{|c|}{ Finland } & \multicolumn{3}{|c|}{ Poland } & \multicolumn{3}{|l|}{ Italy } & \multicolumn{3}{|c|}{ Spain } & \multicolumn{3}{|c|}{ Holland } & \multicolumn{3}{|c|}{ Ten Countries } \\
\hline & $b$ & st & $p$ & $b$ & st & $p$ & $b$ & st & $p$ & $b$ & st & $p$ & $b$ & st & $p$ & $b$ & st & $p$ \\
\hline \multicolumn{19}{|c|}{ Demographic Controls } \\
\hline Age & .01 & .00 & .00 & .00 & .00 & .39 & -.01 & .00 & .00 & .00 & .00 & .12 & .00 & .00 & .10 & .01 & .00 & .01 \\
\hline Male & .15 & .03 & .00 & .19 & .04 & .00 & -.01 & .04 & .87 & .08 & .03 & .02 & .16 & .03 & .00 & .11 & .03 & .00 \\
\hline Education & .08 & .03 & .00 & .09 & .03 & .00 & -.17 & .03 & .00 & .05 & .02 & .01 & -.03 & .02 & .20 & .10 & .04 & .00 \\
\hline \multicolumn{19}{|c|}{ Cultural and Economic factors } \\
\hline NoHome & .24 & .01 & .00 & .02 & .02 & .32 & .20 & .02 & .00 & .18 & .02 & .00 & .22 & .01 & .00 & .19 & .02 & .00 \\
\hline EconRetro & -.02 & .02 & .33 & .10 & .02 & .00 & -.19 & .02 & .00 & .07 & .02 & .00 & .01 & .02 & .61 & -.04 & .03 & .17 \\
\hline Natid & .18 & .03 & .00 & .35 & .04 & .00 & .34 & .04 & .00 & .07 & .04 & .11 & .15 & .03 & .00 & .33 & .06 & .00 \\
\hline Valence & -.00 & .02 & .91 & .15 & .02 & .00 & -.16 & .03 & .00 & .22 & .02 & .00 & -.22 & .02 & .00 & .02 & .06 & .79 \\
\hline \multicolumn{19}{|c|}{ Traditional Social Values } \\
\hline Obedience & .06 & .02 & .00 & .01 & .02 & .60 & .03 & .02 & .11 & .12 & .02 & .00 & .04 & .02 & .01 & .06 & .02 & .01 \\
\hline DifferentRoles & .05 & .01 & .00 & .10 & .02 & .00 & .05 & .02 & .01 & -.04 & .01 & .00 & .02 & .02 & .12 & .07 & .02 & .01 \\
\hline \multicolumn{19}{|l|}{ Issue Salience } \\
\hline MIP-Immig & .29 & .04 & .00 & .29 & .07 & .00 & .25 & .05 & .00 & -.02 & .07 & .80 & .32 & .03 & .00 & .47 & .08 & .00 \\
\hline MIP-Terror & .22 & .09 & .01 & .18 & .05 & .00 & -.01 & .07 & .87 & .19 & .06 & .00 & .01 & .03 & .73 & .17 & .06 & .02 \\
\hline MIP-Gap & -.05 & .03 & .11 & .14 & .04 & .00 & -.14 & .05 & .01 & -.15 & .05 & .00 & -.16 & .04 & .00 & -.06 & .05 & .29 \\
\hline Constant & 1.01 & .12 & .00 & 1.13 & .12 & .00 & 1.94 & .12 & .00 & -.35 & .09 & .00 & 2.03 & .13 & .00 & 1.05 & .34 & .01 \\
\hline \multicolumn{19}{|c|}{ Country-level controls } \\
\hline Foreign & & & & & & & & & & & & & & & & -.07 & .04 & .11 \\
\hline GDPchange & & & & & & & & & & & & & & & & .13 & .11 & .27 \\
\hline Ctd R2 & \multicolumn{3}{|l|}{.49} & \multicolumn{3}{|l|}{.30} & \multicolumn{3}{|l|}{.52} & \multicolumn{3}{|l|}{.44} & \multicolumn{3}{|l|}{.47} & \multicolumn{3}{|l|}{.46} \\
\hline $\mathrm{N}$ & \multicolumn{3}{|l|}{1006} & \multicolumn{3}{|l|}{1016} & \multicolumn{3}{|l|}{1012} & \multicolumn{3}{|l|}{1010} & \multicolumn{3}{|l|}{1016} & \multicolumn{3}{|c|}{10834} \\
\hline
\end{tabular}

$\mathrm{b}=$ coefficient; $\mathrm{st}=$ standard error; $\mathrm{p}=$ probability. Ten Country Model based on Country-clustered OLS with robust standard errors.

For individual country models, data weighted by in-country weights. For pooled model, data weighted to equal Ns across countries 
Table 5: Summary of Findings from Regression Models Reported in Table 4, Parts 1 and 2

\begin{tabular}{|c|c|c|c|c|c|c|c|c|c|c|c|c|c|}
\hline & \multicolumn{13}{|c|}{ Independent Variable } \\
\hline & Age & Male & Educ & $\begin{array}{c}\text { No } \\
\text { Home }\end{array}$ & $\begin{array}{l}\text { Econ } \\
\text { Retro }\end{array}$ & Natid & Valence & $\begin{array}{l}\text { Obed- } \\
\text { ience }\end{array}$ & $\begin{array}{l}\text { Diff } \\
\text { Role }\end{array}$ & $\begin{array}{c}\text { MIP- } \\
\text { Immig }\end{array}$ & $\begin{array}{l}\text { MIP- } \\
\text { Terror }\end{array}$ & $\begin{array}{l}\text { MIP- } \\
\text { Gap }\end{array}$ & $\begin{array}{l}\text { Coeffs } \\
\text { Correct }\end{array}$ \\
\hline Predicted Effect & + & + & - & + & - & + & - & + & + & + & + & - & \\
\hline \multicolumn{14}{|l|}{ Observed Effect } \\
\hline UK & + & + & 0 & + & + & + & + & + & + & + & + & - & $9 / 12$ \\
\hline France & + & + & 0 & + & - & + & - & + & 0 & + & + & - & $10 / 12$ \\
\hline Germany & + & + & 0 & + & 0 & + & - & + & + & + & 0 & 0 & $8 / 12$ \\
\hline Sweden & + & + & 0 & + & - & + & - & + & + & + & 0 & - & $10 / 12$ \\
\hline Denmark & + & + & + & + & 0 & + & 0 & + & 0 & + & 0 & - & $7 / 12$ \\
\hline Finland & + & + & + & + & 0 & + & 0 & + & + & + & + & 0 & $8 / 12$ \\
\hline Poland & 0 & + & + & 0 & + & + & + & 0 & + & + & + & + & $6 / 12$ \\
\hline Italy & - & 0 & - & + & - & + & - & 0 & + & + & 0 & - & $8 / 12$ \\
\hline Spain & 0 & + & + & + & + & 0 & + & - & 0 & 0 & + & - & $4 / 12$ \\
\hline Holland & 0 & + & 0 & + & 0 & + & - & + & 0 & + & 0 & - & $7 / 12$ \\
\hline Ten Countries & + & + & + & + & 0 & + & 0 & + & + & + & + & 0 & $7 / 12$ \\
\hline Coeffs Correct & $6 / 10$ & $9 / 10$ & $1 / 10$ & $9 / 10$ & $3 / 10$ & $9 / 10$ & $5 / 10$ & $7 / 10$ & $6 / 10$ & $9 / 10$ & $5 / 10$ & $7 / 10$ & \\
\hline
\end{tabular}


Table 6: Cluster Analyses of the Eight Component Authoritarian Populism Indicators, UK as an Illustration

\begin{tabular}{|c|c|c|c|c|c|c|c|c|c|}
\hline & \multicolumn{9}{|c|}{ Component Indicator } \\
\hline & $\begin{array}{c}\text { Negative } \\
\text { Immigration } \\
\text { Emotions }\end{array}$ & $\begin{array}{c}\text { Non-EU } \\
\text { Immigration } \\
\text { Bad thing }\end{array}$ & $\begin{array}{c}\text { Disapproval } \\
\text { Of EU }\end{array}$ & $\begin{array}{l}\text { Distrust EU } \\
\text { Institutions }\end{array}$ & $\begin{array}{c}\text { Foreign Policy } \\
\text { Strong and } \\
\text { Tough }\end{array}$ & $\begin{array}{l}\text { Patriotism } \\
\text { Important }\end{array}$ & $\begin{array}{c}\text { Critical of } \\
\text { Human } \\
\text { Rights }\end{array}$ & $\begin{array}{l}\text { Left-Right } \\
\text { Self- } \\
\text { placement }\end{array}$ & $\begin{array}{c}\text { Percentage } \\
\text { In cluster }\end{array}$ \\
\hline \multicolumn{10}{|l|}{ 2-Cluster solution } \\
\hline Cluster 1 & 0.84 & 2.72 & 2.51 & 2.14 & 0.16 & 3.10 & 2.39 & 3.02 & 36 \\
\hline Cluster 2 & 1.10 & 3.19 & 3.23 & 2.61 & 0.38 & 4.01 & 3.27 & 6.13 & 64 \\
\hline \multicolumn{10}{|l|}{ 3-Cluster solution } \\
\hline Cluster 1 & 0.13 & 2.07 & 1.61 & 1.77 & 0.03 & 2.58 & 1.67 & 2.55 & 23 \\
\hline Cluster 2 & 2.20 & 3.99 & 4.25 & 2.86 & 0.43 & 4.10 & 3.78 & 3.93 & 14 \\
\hline Cluster 3 & 1.10 & 3.19 & 3.23 & 2.61 & 0.38 & 4.01 & 3.27 & 6.13 & 64 \\
\hline \multicolumn{10}{|l|}{ 4-Cluster solution } \\
\hline Cluster 1 & 0.13 & 2.07 & 1.61 & 1.77 & 0.03 & 2.58 & 1.67 & 2.55 & 23 \\
\hline Cluster 2 & 2.20 & 3.99 & 4.25 & 2.86 & 0.43 & 4.10 & 3.78 & 3.93 & 14 \\
\hline Cluster 3 & 0.43 & 2.61 & 2.08 & 2.29 & 0.19 & 3.58 & 2.65 & 5.39 & 30 \\
\hline Cluster 4 & 1.72 & 3.73 & 4.30 & 2.91 & 0.55 & 4.41 & 3.84 & 6.81 & 34 \\
\hline Cluster 1 & 0.13 & 2.07 & 1.61 & 1.77 & 0.03 & 2.58 & 1.67 & 2.55 & 23 \\
\hline Cluster 2 & 2.41 & 3.99 & 4.20 & 2.86 & 0.43 & 4.20 & 3.94 & 4.41 & 11 \\
\hline Cluster 3 & 1.21 & 3.96 & 4.46 & 2.86 & 0.43 & 3.61 & 3.04 & 1.61 & 3 \\
\hline Cluster 4 & 0.43 & 2.61 & 2.08 & 2.29 & 0.19 & 3.58 & 2.65 & 5.39 & 30 \\
\hline Cluster 5 & 1.72 & 3.73 & 4.30 & 2.91 & 0.55 & 4.41 & 3.84 & 6.81 & 34 \\
\hline Overall UK average & 1.00 & 3.02 & 2.96 & 2.43 & 0.30 & 3.67 & 2.94 & 4.96 & \\
\hline Range & $0-4$ & $1-5$ & $1-5$ & $1-3$ & $0-1$ & $1-5$ & $1-5$ & $0-10$ & \\
\hline
\end{tabular}


Table 7: Estimated Political Tribes in Ten European Countries, based on Cluster Analyses Conducted in Table 6 and Annex 2

\begin{tabular}{|c|c|c|c|c|c|}
\hline Country and number of clusters & Political Tribe & $\begin{array}{l}\text { Percentage } \\
\text { of Electorate }\end{array}$ & Country and number of clusters & Political Tribe & $\begin{array}{l}\text { Percentage } \\
\text { of Electorate }\end{array}$ \\
\hline \multirow[t]{4}{*}{ UK: 4-cluster solution } & Left liberals & 23 & Finland: 6 -cluster solution & Left liberals & 8 \\
\hline & Left AP & 14 & & Left AP & 14 \\
\hline & Centre-right liberals & 30 & & Centre-left liberals & 20 \\
\hline & Right AP & 34 & & Centre-right liberals & 22 \\
\hline \multirow[t]{3}{*}{ France: 3-cluster solution } & Left liberals & 34 & & Centre-right AP & 25 \\
\hline & Centre-right AP & 41 & & Right AP & 11 \\
\hline & Right AP & 25 & Poland & Left liberals & 22 \\
\hline \multirow[t]{4}{*}{ Germany: 4-cluster solution } & Left liberals & 19 & & Centre-left AP & 23 \\
\hline & Centre-left liberals & 50 & & Centre-right liberals & 35 \\
\hline & Centre-right AP & 24 & & Right AP & 20 \\
\hline & Right AP & 7 & Italy & Left liberals & 13 \\
\hline \multirow[t]{3}{*}{ Sweden: 3-cluster solution } & Left liberals & 41 & & Left AP & 16 \\
\hline & Right liberals & 16 & & Centre-right AP & 47 \\
\hline & Centre-right AP & 43 & & Right liberals & 25 \\
\hline \multirow[t]{8}{*}{ Denmark: 4-cluster solution } & Left liberals & 26 & Spain & Left liberals & 23 \\
\hline & Centre-left liberals & 24 & & Centre-left liberals & 46 \\
\hline & Centre-right AP & 37 & & Right AP & 36 \\
\hline & Right AP & 12 & Holland & Left liberals & 10 \\
\hline & & & & Centre-left liberals & 26 \\
\hline & & & & Centre-left AP & 15 \\
\hline & & & & Centre-right liberals & 33 \\
\hline & & & & Right AP & 15 \\
\hline
\end{tabular}

AP signifies Authoritarian Populist; data weighted by in-country weights 
Table 8: Bivariate Relationship between Party Family Vote Intention Membership of an Authoritarian Populist tribe, across ten pooled European Countries

\begin{tabular}{|l|c|c|c|c|}
\hline & \multicolumn{3}{|c|}{ AP tribe status } & \\
\hline & $\begin{array}{c}\text { Not in an AP } \\
\text { Tribe (55\%) }\end{array}$ & $\begin{array}{c}\text { Member of } \\
\text { Left AP tribe (8\%) }\end{array}$ & $\begin{array}{c}\text { Member of } \\
\text { Right AP tribe (37\%) }\end{array}$ & $\begin{array}{c}\text { Percentage of all those } \\
\text { with vote intention }\end{array}$ \\
\hline Party Family & & & & \\
\hline Far Left & 13 & 12 & 15 & 11 \\
\hline Centre Left & 40 & 19 & 13 & 27 \\
\hline Centre & 16 & 16 & 31 & 15 \\
\hline Centre Right & 27 & 28 & 35 & 19 \\
\hline Right Wing Populist & 6 & 25 & & 19 \\
\hline
\end{tabular}

Column percentages reported; data weighted to equal Ns across countries 
Annex 1. Country-level measures: size of foreign born population 2015 and Annual Average percentage growth in GDP $2006-2015$

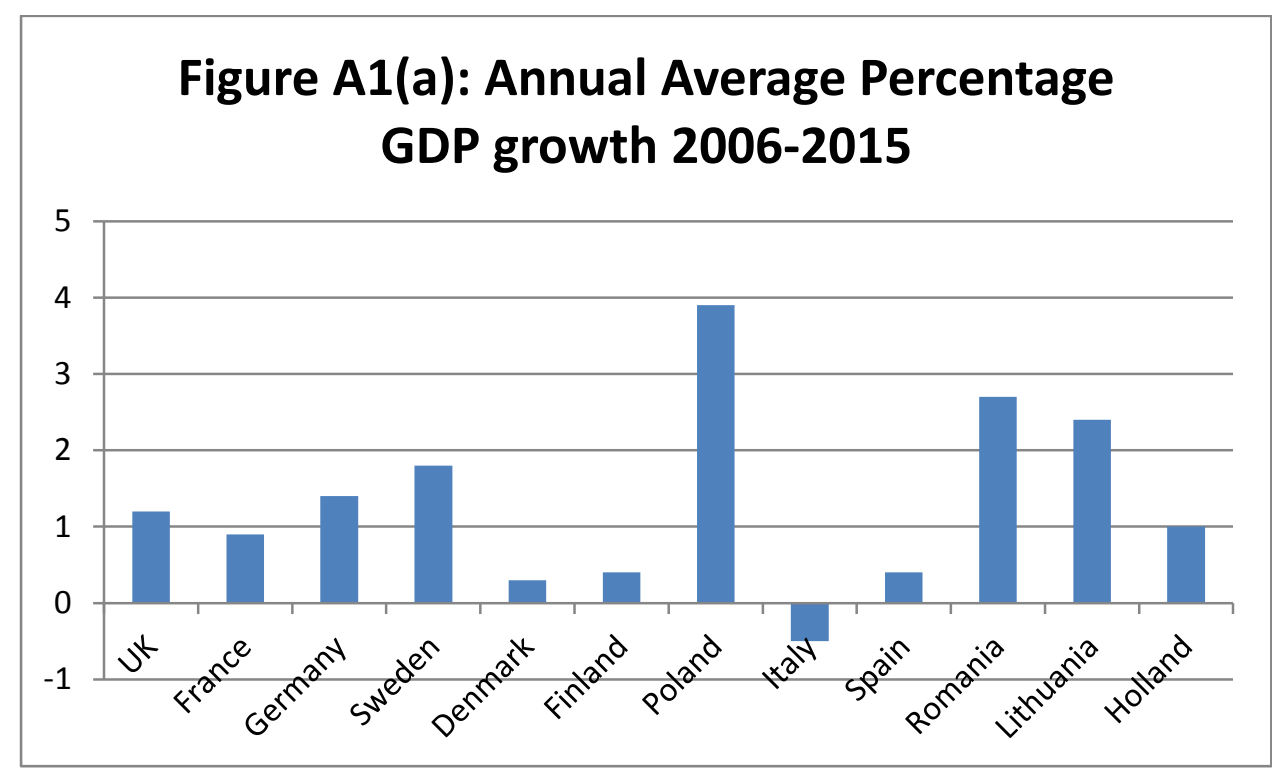




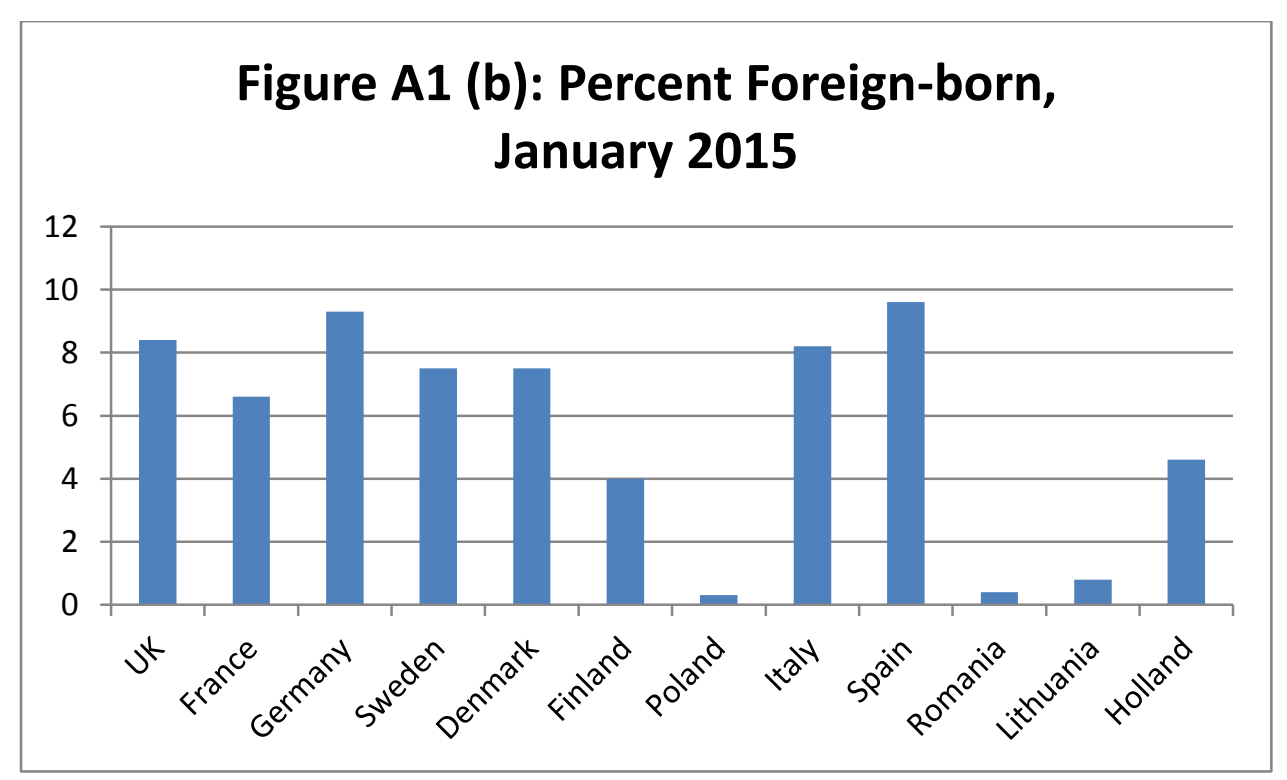


Annex 2: Country-specific Cluster Analyses of the Eight Component Authoritarian Populism Indicators

Table A2.1: France

\begin{tabular}{|c|c|c|c|c|c|c|c|c|c|}
\hline & \multicolumn{9}{|c|}{ Component Indicator } \\
\hline & $\begin{array}{c}\text { Negative } \\
\text { Immigration } \\
\text { Emotions }\end{array}$ & $\begin{array}{c}\text { Non-EU } \\
\text { Immigration } \\
\text { Bad thing }\end{array}$ & $\begin{array}{c}\text { Disapproval } \\
\text { Of EU }\end{array}$ & $\begin{array}{l}\text { Distrust EU } \\
\text { Institutions }\end{array}$ & $\begin{array}{c}\text { Foreign Policy } \\
\text { Strong and } \\
\text { Tough }\end{array}$ & $\begin{array}{l}\text { Patriotism } \\
\text { Important }\end{array}$ & $\begin{array}{c}\text { Critical of } \\
\text { Human } \\
\text { Rights }\end{array}$ & $\begin{array}{l}\text { Left-Right } \\
\text { Self- } \\
\text { placement }\end{array}$ & $\begin{array}{c}\text { Percentage } \\
\text { In cluster }\end{array}$ \\
\hline \multicolumn{10}{|l|}{ 2-Cluster solution } \\
\hline Cluster 1 & 1.60 & 3.96 & 2.78 & 2.44 & 0.53 & 4.25 & 3.54 & 7.07 & 66 \\
\hline Cluster 2 & 0.78 & 3.07 & 2.66 & 2.41 & 0.25 & 3.65 & 2.78 & 2.04 & 34 \\
\hline \multicolumn{10}{|l|}{ 3-Cluster solution } \\
\hline Cluster 1 & 1.31 & 3.69 & 2.47 & 2.36 & 0.47 & 4.10 & 2.36 & 5.53 & 41 \\
\hline Cluster 2 & 2.03 & 4.34 & 3.22 & 2.54 & 0.61 & 4.50 & 3.89 & 9.24 & 25 \\
\hline Cluster 3 & 0.78 & 3.07 & 2.66 & 2.41 & 0.25 & 3.65 & 2.78 & 2.04 & 34 \\
\hline \multicolumn{10}{|l|}{ 4-Cluster solution } \\
\hline Cluster 1 & 1.31 & 3.69 & 2.47 & 2.36 & 0.47 & 4.10 & 2.36 & 5.53 & 41 \\
\hline Cluster 2 & 2.03 & 4.34 & 3.22 & 2.54 & 0.61 & 4.50 & 3.89 & 9.24 & 25 \\
\hline Cluster 3 & 0.61 & 2.90 & 2.46 & 2.36 & 0.22 & 3.53 & 2.64 & 2.15 & 30 \\
\hline Cluster 4 & 2.31 & 4.50 & 4.35 & 2.83 & 0.54 & 4.73 & 3.96 & 1.19 & 3 \\
\hline Range & $0-4$ & $1-5$ & $1-5$ & $1-3$ & $0-1$ & $1-5$ & $1-5$ & $0-10$ & \\
\hline
\end{tabular}


Table A2.2: Germany

\begin{tabular}{|c|c|c|c|c|c|c|c|c|c|}
\hline & \multicolumn{9}{|c|}{ Component Indicator } \\
\hline & $\begin{array}{c}\text { Negative } \\
\text { Immigration } \\
\text { Emotions }\end{array}$ & $\begin{array}{c}\text { Non-EU } \\
\text { Immigration } \\
\text { Bad thing }\end{array}$ & $\begin{array}{c}\text { Disapproval } \\
\text { Of } E U\end{array}$ & $\begin{array}{l}\text { Distrust EU } \\
\text { Institutions }\end{array}$ & $\begin{array}{c}\text { Foreign Policy } \\
\text { Strong and } \\
\text { Tough }\end{array}$ & $\begin{array}{l}\text { Patriotism } \\
\text { Important }\end{array}$ & $\begin{array}{l}\text { Critical of } \\
\text { Human } \\
\text { Rights }\end{array}$ & $\begin{array}{c}\text { Left-Right } \\
\text { Self- } \\
\text { placement }\end{array}$ & $\begin{array}{c}\text { Percentage } \\
\text { In cluster }\end{array}$ \\
\hline \multicolumn{10}{|l|}{ 2-Cluster solution } \\
\hline Cluster 1 & 1.20 & 3.60 & 2.56 & 2.39 & 0.14 & 3.58 & 3.10 & 5.40 & 81 \\
\hline Cluster 2 & 0.67 & 3.03 & 2.04 & 2.26 & 0.05 & 2.60 & 2.27 & 2.14 & 19 \\
\hline \multicolumn{10}{|l|}{ 3-Cluster solution } \\
\hline Cluster 1 & 1.17 & 3.53 & 2.54 & 2.37 & 0.12 & 3.53 & 3.07 & 5.14 & 74 \\
\hline Cluster 2 & 1.47 & 4.30 & 2.70 & 2.55 & 0.28 & 4.12 & 3.48 & 8.22 & 7 \\
\hline Cluster 3 & 0.67 & 3.03 & 2.04 & 2.26 & 0.05 & 2.60 & 2.27 & 2.14 & 19 \\
\hline \multicolumn{10}{|l|}{ 4-Cluster solution } \\
\hline Cluster 1 & 2.24 & 4.46 & 3.50 & 2.76 & 0.19 & 3.94 & 3.76 & 6.17 & 24 \\
\hline Cluster 2 & 0.66 & 3.09 & 2.08 & 2.18 & 0.09 & 3.34 & 2.73 & 4.64 & 50 \\
\hline Cluster 3 & 1.47 & 4.30 & 2.70 & 2.55 & 0.28 & 4.12 & 3.48 & 8.22 & 7 \\
\hline Cluster 4 & 0.67 & 3.03 & 2.04 & 2.26 & 0.05 & 2.60 & 2.27 & 2.14 & 19 \\
\hline Cluster 1 & 2.24 & 4.46 & 3.50 & 2.76 & 0.19 & 3.94 & 3.76 & 6.17 & 24 \\
\hline Cluster 2 & 0.66 & 3.09 & 2.08 & 2.18 & 0.09 & 3.34 & 2.73 & 4.64 & 50 \\
\hline Cluster 3 & 1.47 & 4.30 & 2.70 & 2.55 & 0.28 & 4.12 & 3.48 & 8.22 & 7 \\
\hline Cluster 4 & 1.59 & 3.90 & 2.84 & 2.48 & 0.04 & 3.61 & 2.90 & 1.76 & 5 \\
\hline Cluster 5 & 0.25 & 2.63 & 1.67 & 2.16 & 0.05 & 2.14 & 1.97 & 2.32 & 13 \\
\hline Overall average & 1.10 & 3.50 & 2.46 & 2.36 & 0.12 & 3.40 & 2.95 & 4.79 & \\
\hline Range & $0-4$ & $1-5$ & $1-5$ & $1-3$ & $0-1$ & $1-5$ & $1-5$ & $0-10$ & \\
\hline
\end{tabular}


Table A2.3: Sweden

\begin{tabular}{|c|c|c|c|c|c|c|c|c|c|}
\hline & \multicolumn{9}{|c|}{ Component Indicator } \\
\hline & $\begin{array}{c}\text { Negative } \\
\text { Immigration } \\
\text { Emotions }\end{array}$ & $\begin{array}{c}\text { Non-EU } \\
\text { Immigration } \\
\text { Bad thing }\end{array}$ & $\begin{array}{c}\text { Disapproval } \\
\text { Of EU }\end{array}$ & $\begin{array}{l}\text { Distrust EU } \\
\text { Institutions }\end{array}$ & $\begin{array}{c}\text { Foreign Policy } \\
\text { Strong and } \\
\text { Tough }\end{array}$ & $\begin{array}{l}\text { Patriotism } \\
\text { Important }\end{array}$ & $\begin{array}{c}\text { Critical of } \\
\text { Human } \\
\text { Rights }\end{array}$ & $\begin{array}{l}\text { Left-Right } \\
\text { Self- } \\
\text { placement }\end{array}$ & $\begin{array}{c}\text { Percentage } \\
\text { In cluster }\end{array}$ \\
\hline \multicolumn{10}{|l|}{ 2-Cluster solution } \\
\hline Cluster 1 & 2.06 & 3.92 & 3.35 & 2.43 & 0.25 & 3.89 & 3.25 & 6.89 & 59 \\
\hline Cluster 2 & 0.61 & 2.52 & 2.68 & 2.05 & 0.04 & 2.78 & 2.08 & 2.87 & 41 \\
\hline \multicolumn{10}{|l|}{ 3-Cluster solution } \\
\hline Cluster 1 & 2.44 & 4.31 & 3.69 & 2.60 & 0.29 & 4.14 & 3.54 & 6.76 & 43 \\
\hline Cluster 2 & 0.61 & 2.42 & 2.03 & 1.80 & 0.10 & 2.90 & 2.12 & 7.40 & 16 \\
\hline Cluster 3 & 0.61 & 2.52 & 2.68 & 2.05 & 0.04 & 2.78 & 2.08 & 2.87 & 41 \\
\hline \multicolumn{10}{|l|}{ 4-Cluster solution } \\
\hline Cluster 1 & 2.44 & 4.31 & 3.69 & 2.60 & 0.29 & 4.14 & 3.54 & 6.76 & 43 \\
\hline Cluster 2 & 0.61 & 2.42 & 2.03 & 1.80 & 0.10 & 2.90 & 2.12 & 7.40 & 16 \\
\hline Cluster 3 & 0.46 & 2.38 & 2.60 & 2.02 & 0.03 & 2.68 & 1.97 & 2.92 & 39 \\
\hline Cluster 4 & 3.05 & 4.70 & 3.95 & 2.65 & 0.25 & 4.40 & 3.80 & 1.75 & 2 \\
\hline Range & $0-4$ & $1-5$ & $1-5$ & $1-3$ & $0-1$ & $1-5$ & $1-5$ & $0-10$ & \\
\hline
\end{tabular}


Table A2.4: Denmark

\begin{tabular}{|c|c|c|c|c|c|c|c|c|c|}
\hline & \multicolumn{9}{|c|}{ Component Indicator } \\
\hline & $\begin{array}{c}\text { Negative } \\
\text { Immigration } \\
\text { Emotions }\end{array}$ & $\begin{array}{c}\text { Non-EU } \\
\text { Immigration } \\
\text { Bad thing }\end{array}$ & $\begin{array}{c}\text { Disapproval } \\
\text { Of EU }\end{array}$ & $\begin{array}{l}\text { Distrust EU } \\
\text { Institutions }\end{array}$ & $\begin{array}{c}\text { Foreign Policy } \\
\text { Strong and } \\
\text { Tough }\end{array}$ & $\begin{array}{l}\text { Patriotism } \\
\text { Important }\end{array}$ & $\begin{array}{l}\text { Critical of } \\
\text { Human } \\
\text { Rights }\end{array}$ & $\begin{array}{l}\text { Left-Right } \\
\text { Self- } \\
\text { placement }\end{array}$ & $\begin{array}{c}\text { Percentage } \\
\text { In cluster }\end{array}$ \\
\hline \multicolumn{10}{|c|}{\begin{tabular}{|l|l|l} 
2-Cluster solution & & \\
\end{tabular}} \\
\hline Cluster 1 & 0.75 & 3.18 & 2.60 & 2.13 & 0.07 & 2.89 & 2.15 & 2.34 & 26 \\
\hline Cluster 2 & 1.32 & 3.84 & 2.69 & 2.14 & 0.20 & 3.54 & 2.95 & 6.42 & 74 \\
\hline \multicolumn{10}{|l|}{ 3-Cluster solution } \\
\hline Cluster 1 & 0.75 & 3.18 & 2.60 & 2.13 & 0.07 & 2.89 & 2.15 & 2.34 & 26 \\
\hline Cluster 2 & 1.21 & 3.83 & 2.72 & 2.18 & 0.18 & 3.52 & 2.88 & 3.83 & 62 \\
\hline Cluster 3 & 1.82 & 3.92 & 2.58 & 1.94 & 0.28 & 3.57 & 3.27 & 3.92 & 12 \\
\hline \multicolumn{10}{|l|}{ 4-Cluster solution } \\
\hline Cluster 1 & 0.75 & 3.18 & 2.60 & 2.13 & 0.07 & 2.89 & 2.15 & 2.34 & 26 \\
\hline Cluster 2 & 1.6 & 4.21 & 2.94 & 2.28 & 0.23 & 3.86 & 3.10 & 6.67 & 37 \\
\hline Cluster 3 & 0.45 & 3.19 & 2.35 & 2.00 & 0.09 & 3.00 & 2.51 & 4.75 & 24 \\
\hline Cluster 4 & 1.82 & 3.92 & 2.58 & 1.94 & 0.28 & 3.57 & 3.27 & 8.75 & 12 \\
\hline Cluster 1 & 0.45 & 2.93 & 2.50 & 2.02 & 0.03 & 2.66 & 1.95 & 2.27 & 22 \\
\hline Cluster 2 & 2.31 & 4.49 & 3.15 & 2.69 & 0.31 & 4.07 & 3.20 & 2.72 & 4 \\
\hline Cluster 3 & 1.6 & 4.21 & 2.94 & 2.28 & 0.23 & 3.86 & 3.10 & 6.67 & 37 \\
\hline Cluster 4 & 0.45 & 3.19 & 2.35 & 2.00 & 0.09 & 3.00 & 2.51 & 4.75 & 24 \\
\hline Cluster 5 & 1.82 & 3.92 & 2.58 & 1.94 & 0.28 & 3.57 & 3.27 & 8.75 & 12 \\
\hline Overall average & 1.16 & 3.66 & 2.67 & 2.13 & 0.16 & 3.36 & 2.73 & 5.32 & \\
\hline Range & $0-4$ & $1-5$ & $1-5$ & $1-3$ & $0-1$ & $1-5$ & $1-5$ & $0-10$ & \\
\hline
\end{tabular}


Table A2.5: Finland

\begin{tabular}{|c|c|c|c|c|c|c|c|c|c|}
\hline & \multicolumn{9}{|c|}{ Component Indicator } \\
\hline & $\begin{array}{c}\text { Negative } \\
\text { Immigration } \\
\text { Emotions }\end{array}$ & \begin{tabular}{|} 
Non-EU \\
Immigration \\
Bad thing
\end{tabular} & $\begin{array}{c}\text { Disapproval } \\
\text { Of EU }\end{array}$ & $\begin{array}{l}\text { Distrust EU } \\
\text { Institutions }\end{array}$ & $\begin{array}{c}\text { Foreign Policy } \\
\text { Strong and } \\
\text { Tough }\end{array}$ & $\begin{array}{l}\text { Patriotism } \\
\text { Important }\end{array}$ & $\begin{array}{c}\text { Critical of } \\
\text { Human } \\
\text { Rights }\end{array}$ & $\begin{array}{c}\text { Left-Right } \\
\text { Self- } \\
\text { placement }\end{array}$ & $\begin{array}{c}\text { Percentage } \\
\text { In cluster }\end{array}$ \\
\hline \multicolumn{10}{|l|}{ 2-Cluster solution } \\
\hline Cluster 1 & 1.54 & 3.72 & 2.48 & 2.18 & 0.26 & 3.98 & 3.22 & 6.02 & 78 \\
\hline Cluster 2 & 1.35 & 3.31 & 2.14 & 2.10 & 0.12 & 3.39 & 2.57 & 2.11 & 22 \\
\hline \multicolumn{10}{|l|}{ 3-Cluster solution } \\
\hline Cluster 1 & 1.57 & 3.86 & 2.78 & 2.35 & 0.22 & 3.94 & 3.25 & 4.82 & 45 \\
\hline Cluster 2 & 1.28 & 3.51 & 2.06 & 1.94 & 0.31 & 4.02 & 3.18 & 7.73 & 33 \\
\hline Cluster 3 & 1.35 & 3.31 & 2.14 & 2.10 & 0.12 & 3.39 & 2.57 & 2.11 & 22 \\
\hline \multicolumn{10}{|l|}{ 4-Cluster solution } \\
\hline Cluster 1 & 1.57 & 3.86 & 2.78 & 2.35 & 0.22 & 3.94 & 3.25 & 4.82 & 45 \\
\hline Cluster 2 & 1.28 & 3.51 & 2.06 & 1.94 & 0.31 & 4.02 & 3.18 & 7.73 & 33 \\
\hline Cluster 3 & 0.29 & 2.23 & 1.45 & 1.77 & 0.00 & 2.77 & 1.53 & 2.12 & 8 \\
\hline Cluster 4 & 2.11 & 4.05 & 2.62 & 2.33 & 0.20 & 3.82 & 3.31 & 2.11 & 14 \\
\hline Cluster 1 & 1.57 & 3.86 & 2.78 & 2.35 & 0.22 & 3.94 & 3.25 & 4.82 & 45 \\
\hline Cluster 2 & 0.47 & 2.91 & 1.70 & 1.73 & 0.24 & 3.89 & 2.70 & 7.50 & 22 \\
\hline Cluster 3 & 2.81 & 4.66 & 2.73 & 2.35 & 0.45 & 4.29 & 4.08 & 8.16 & 11 \\
\hline Cluster 4 & 0.29 & 2.23 & 1.45 & 1.77 & 0.00 & 2.77 & 1.53 & 2.12 & 8 \\
\hline Cluster 5 & 2.11 & 4.05 & 2.62 & 2.33 & 0.20 & 3.82 & 3.31 & 2.11 & 14 \\
\hline \multicolumn{10}{|l|}{ 6-Cluster solution } \\
\hline Cluster 1 & 2.36 & 4.34 & 3.15 & 2.57 & 0.27 & 4.18 & 3.62 & 5.25 & 25 \\
\hline Cluster 2 & 0.60 & 3.27 & 2.33 & 2.08 & 0.16 & 3.66 & 2.80 & 4.30 & 20 \\
\hline Cluster 3 & 0.47 & 2.91 & 1.70 & 1.73 & 0.24 & 3.89 & 2.70 & 7.50 & 22 \\
\hline Cluster 4 & 2.81 & 4.66 & 2.73 & 2.35 & 0.45 & 4.29 & 4.08 & 8.16 & 11 \\
\hline Cluster 5 & 0.29 & 2.23 & 1.45 & 1.77 & 0.00 & 2.77 & 1.53 & 2.12 & 8 \\
\hline Cluster 6 & 2.11 & 4.05 & 2.62 & 2.33 & 0.20 & 3.82 & 3.31 & 2.11 & 14 \\
\hline Overall average & 1.43 & 3.62 & 2.40 & 2.16 & 0.23 & 3.84 & 3.07 & 5.10 & \\
\hline Range & $0-4$ & $1-5$ & $1-5$ & $1-3$ & $0-1$ & $1-5$ & $1-5$ & $0-10$ & \\
\hline
\end{tabular}


Table A2.6: Poland

\begin{tabular}{|c|c|c|c|c|c|c|c|c|c|}
\hline & \multicolumn{9}{|c|}{ Component Indicator } \\
\hline & $\begin{array}{c}\text { Negative } \\
\text { Immigration } \\
\text { Emotions }\end{array}$ & $\begin{array}{c}\text { Non-EU } \\
\text { Immigration } \\
\text { Bad thing }\end{array}$ & $\begin{array}{c}\text { Disapproval } \\
\text { Of } E U\end{array}$ & $\begin{array}{l}\text { Distrust EU } \\
\text { Institutions }\end{array}$ & $\begin{array}{c}\text { Foreign Policy } \\
\text { Strong and } \\
\text { Tough }\end{array}$ & $\begin{array}{l}\text { Patriotism } \\
\text { Important }\end{array}$ & $\begin{array}{l}\text { Critical of } \\
\text { Human } \\
\text { Rights }\end{array}$ & $\begin{array}{c}\text { Left-Right } \\
\text { Self- } \\
\text { placement }\end{array}$ & $\begin{array}{c}\text { Percentage } \\
\text { In cluster }\end{array}$ \\
\hline \multicolumn{10}{|l|}{ 2-Cluster solution } \\
\hline Cluster 1 & 1.53 & 3.68 & 2.04 & 2.01 & 0.33 & 4.05 & 3.20 & 6.22 & 78 \\
\hline Cluster 2 & 1.20 & 3.37 & 1.56 & 1.48 & 0.17 & 3.74 & 2.94 & 1.97 & 22 \\
\hline \multicolumn{10}{|l|}{ 3-Cluster solution } \\
\hline Cluster 1 & 1.93 & 4.17 & 2.55 & 2.55 & 0.55 & 4.42 & 3.74 & 9.28 & 20 \\
\hline Cluster 2 & 1.43 & 3.56 & 1.91 & 1.87 & 0.28 & 3.95 & 3.06 & 5.41 & 58 \\
\hline Cluster 3 & 1.20 & 3.37 & 1.56 & 1.48 & 0.17 & 3.74 & 2.94 & 1.97 & 22 \\
\hline \multicolumn{10}{|l|}{ 4-Cluster solution } \\
\hline Cluster 1 & 1.93 & 4.17 & 2.55 & 2.55 & 0.55 & 4.42 & 3.74 & 9.28 & 20 \\
\hline Cluster 2 & 1.33 & 3.41 & 1.67 & 1.80 & 0.26 & 3.75 & 2.62 & 5.75 & 34 \\
\hline Cluster 3 & 1.58 & 3.77 & 2.77 & 1.99 & 0.31 & 4.25 & 3.75 & 4.89 & 24 \\
\hline Cluster 4 & 1.20 & 3.37 & 1.56 & 1.48 & 0.17 & 3.74 & 2.94 & 1.97 & 22 \\
\hline Cluster 1 & 1.93 & 4.17 & 2.55 & 2.55 & 0.55 & 4.42 & 3.74 & 9.28 & 20 \\
\hline Cluster 2 & 1.33 & 3.41 & 1.67 & 1.80 & 0.26 & 3.75 & 2.62 & 5.75 & 34 \\
\hline Cluster 3 & 1.58 & 3.77 & 2.77 & 1.99 & 0.31 & 4.25 & 3.75 & 4.89 & 24 \\
\hline Cluster 4 & 0.90 & 3.12 & 1.38 & 1.37 & 0.16 & 3.66 & 2.66 & 2.17 & 17 \\
\hline Cluster 5 & 2.38 & 4.35 & 2.27 & 1.89 & 0.24 & 4.05 & 4.05 & 1.19 & 5 \\
\hline Overall average & 1.46 & 3.61 & 1.92 & 1.90 & 0.30 & 3.98 & 3.14 & 5.30 & \\
\hline Range & $0-4$ & $1-5$ & $1-5$ & $1-3$ & $0-1$ & $1-5$ & $1-5$ & $0-10$ & \\
\hline
\end{tabular}


Table A2.7: Italy

\begin{tabular}{|c|c|c|c|c|c|c|c|c|c|}
\hline & \multicolumn{9}{|c|}{ Component Indicator } \\
\hline & $\begin{array}{c}\text { Negative } \\
\text { Immigration } \\
\text { Emotions }\end{array}$ & $\begin{array}{c}\text { Non-EU } \\
\text { Immigration } \\
\text { Bad thing }\end{array}$ & $\begin{array}{c}\text { Disapproval } \\
\text { Of EU }\end{array}$ & $\begin{array}{l}\text { Distrust EU } \\
\text { Institutions }\end{array}$ & $\begin{array}{c}\text { Foreign Policy } \\
\text { Strong and } \\
\text { Tough }\end{array}$ & $\begin{array}{l}\text { Patriotism } \\
\text { Important }\end{array}$ & $\begin{array}{l}\text { Critical of } \\
\text { Human } \\
\text { Rights }\end{array}$ & $\begin{array}{l}\text { Left-Right } \\
\text { Self- } \\
\text { placement }\end{array}$ & $\begin{array}{c}\text { Percentage } \\
\text { In cluster }\end{array}$ \\
\hline \multicolumn{10}{|c|}{\begin{tabular}{|l|l|l|} 
2-Cluster solution & & \\
\end{tabular}} \\
\hline Cluster 1 & 1.42 & 3.74 & 2.62 & 2.19 & 0.38 & 3.86 & 3.26 & 4.25 & 75 \\
\hline Cluster 2 & 0.71 & 2.95 & 2.09 & 2.09 & 0.21 & 3.53 & 2.66 & 8.60 & 25 \\
\hline \multicolumn{10}{|l|}{ 3-Cluster solution } \\
\hline Cluster 1 & 1.43 & 3.80 & 2.41 & 2.10 & 0.35 & 3.87 & 3.32 & 5.32 & 47 \\
\hline Cluster 2 & 1.40 & 3.64 & 3.03 & 2.36 & 0.44 & 3.84 & 3.15 & 2.22 & 28 \\
\hline Cluster 3 & 0.71 & 2.95 & 2.09 & 2.09 & 0.21 & 3.53 & 2.66 & 8.60 & 25 \\
\hline \multicolumn{10}{|l|}{ 4-Cluster solution } \\
\hline Cluster 1 & 1.43 & 3.80 & 2.41 & 2.10 & 0.35 & 3.87 & 3.32 & 5.32 & 47 \\
\hline Cluster 2 & 0.87 & 3.17 & 2.97 & 2.23 & 0.35 & 3.58 & 2.65 & 3.73 & 13 \\
\hline Cluster 3 & 1.93 & 4.10 & 3.10 & 2.47 & 0.52 & 4.11 & 3.66 & 0.69 & 15 \\
\hline Cluster 4 & 0.71 & 2.95 & 2.09 & 2.09 & 0.21 & 3.53 & 2.66 & 8.60 & 25 \\
\hline Cluster 1 & 1.43 & 3.80 & 2.41 & 2.10 & 0.35 & 3.87 & 3.32 & 5.32 & 47 \\
\hline Cluster 2 & 0.87 & 3.17 & 2.97 & 2.23 & 0.35 & 3.58 & 2.65 & 3.73 & 13 \\
\hline Cluster 3 & 1.93 & 4.10 & 3.10 & 2.47 & 0.52 & 4.11 & 3.66 & 0.69 & 15 \\
\hline Cluster 4 & 1.58 & 4.27 & 2.75 & 2.19 & 0.39 & 4.18 & 2.59 & 9.18 & 6 \\
\hline Cluster 5 & 0.46 & 2.56 & 1.90 & 2.05 & 0.16 & 3.34 & 2.68 & 8.43 & 19 \\
\hline Overall average & 1.22 & 3.53 & 2.48 & 2.48 & 0.33 & 3.77 & 3.09 & 5.45 & \\
\hline Range & $0-4$ & $1-5$ & $1-5$ & $1-3$ & $0-1$ & $1-5$ & $1-5$ & $0-10$ & \\
\hline
\end{tabular}


Table A2.8: Spain

\begin{tabular}{|c|c|c|c|c|c|c|c|c|c|}
\hline & \multicolumn{9}{|c|}{ Component Indicator } \\
\hline & $\begin{array}{c}\text { Negative } \\
\text { Immigration } \\
\text { Emotions }\end{array}$ & $\begin{array}{c}\text { Non-EU } \\
\text { Immigration } \\
\text { Bad thing }\end{array}$ & $\begin{array}{c}\text { Disapproval } \\
\text { Of EU }\end{array}$ & $\begin{array}{l}\text { Distrust EU } \\
\text { Institutions }\end{array}$ & $\begin{array}{c}\text { Foreign Policy } \\
\text { Strong and } \\
\text { Tough }\end{array}$ & $\begin{array}{l}\text { Patriotism } \\
\text { Important }\end{array}$ & $\begin{array}{c}\text { Critical of } \\
\text { Human } \\
\text { Rights }\end{array}$ & $\begin{array}{l}\text { Left-Right } \\
\text { Self- } \\
\text { placement }\end{array}$ & $\begin{array}{c}\text { Percentage } \\
\text { In cluster }\end{array}$ \\
\hline \multicolumn{10}{|l|}{ 2-Cluster solution } \\
\hline Cluster 1 & 0.71 & 3.12 & 2.05 & 2.17 & 0.19 & 3.29 & 2.86 & 3.33 & 70 \\
\hline Cluster 2 & 0.96 & 3.51 & 1.62 & 1.83 & 0.35 & 4.07 & 3.34 & 7.94 & 30 \\
\hline \multicolumn{10}{|l|}{ 3-Cluster solution } \\
\hline Cluster 1 & 0.60 & 2.98 & 2.43 & 2.41 & 0.14 & 2.85 & 2.54 & 1.16 & 23 \\
\hline Cluster 2 & 0.77 & 3.19 & 1.87 & 2.06 & 0.21 & 2.49 & 3.00 & 4.30 & 47 \\
\hline Cluster 3 & 0.96 & 3.51 & 1.62 & 1.83 & 0.35 & 4.07 & 3.34 & 7.94 & 30 \\
\hline \multicolumn{10}{|l|}{ 4-Cluster solution } \\
\hline Cluster 1 & 0.60 & 2.98 & 2.43 & 2.41 & 0.14 & 2.85 & 2.54 & 1.16 & 23 \\
\hline Cluster 2 & 0.77 & 3.19 & 1.87 & 2.06 & 0.21 & 2.49 & 3.00 & 4.30 & 47 \\
\hline Cluster 3 & 1.00 & 3.48 & 1.41 & 1.74 & 0.38 & 4.35 & 3.41 & 8.05 & 27 \\
\hline Cluster 4 & 0.62 & 3.71 & 3.47 & 2.67 & 0.14 & 1.71 & 2.81 & 6.95 & 3 \\
\hline Range & $0-4$ & $1-5$ & $1-5$ & $1-3$ & $0-1$ & $1-5$ & $1-5$ & $0-10$ & \\
\hline
\end{tabular}


Table A2.9: Holland

\begin{tabular}{|c|c|c|c|c|c|c|c|c|c|}
\hline & \multicolumn{9}{|c|}{ Component Indicator } \\
\hline & $\begin{array}{c}\text { Negative } \\
\text { Immigration } \\
\text { Emotions }\end{array}$ & $\begin{array}{c}\text { Non-EU } \\
\text { Immigration } \\
\text { Bad thing }\end{array}$ & $\begin{array}{c}\text { Disapproval } \\
\text { Of } E U\end{array}$ & $\begin{array}{l}\text { Distrust EU } \\
\text { Institutions }\end{array}$ & $\begin{array}{c}\text { Foreign Policy } \\
\text { Strong and } \\
\text { Tough }\end{array}$ & $\begin{array}{l}\text { Patriotism } \\
\text { Important }\end{array}$ & $\begin{array}{l}\text { Critical of } \\
\text { Human } \\
\text { Rights }\end{array}$ & $\begin{array}{c}\text { Left-Right } \\
\text { Self- } \\
\text { placement }\end{array}$ & $\begin{array}{c}\text { Percentage } \\
\text { In cluster }\end{array}$ \\
\hline \multicolumn{10}{|l|}{ 2-Cluster solution } \\
\hline Cluster 1 & 1.35 & 3.76 & 2.79 & 2.45 & 0.31 & 3.53 & 3.20 & 6.94 & 49 \\
\hline Cluster 2 & 0.98 & 3.28 & 2.71 & 2.17 & 0.23 & 3.28 & 2.68 & 3.70 & 51 \\
\hline \multicolumn{10}{|l|}{ 3-Cluster solution } \\
\hline Cluster 1 & 1.35 & 3.76 & 2.79 & 2.45 & 0.31 & 3.53 & 3.20 & 6.94 & 49 \\
\hline Cluster 2 & 2.14 & 4.23 & 3.98 & 2.78 & 0.41 & 3.80 & 3.57 & 4.50 & 15 \\
\hline Cluster 3 & 0.51 & 2.89 & 2.19 & 1.93 & 0.15 & 3.06 & 2.31 & 3.37 & 36 \\
\hline \multicolumn{10}{|l|}{ 4-Cluster solution } \\
\hline Cluster 1 & 1.35 & 3.76 & 2.79 & 2.45 & 0.31 & 3.53 & 3.20 & 6.94 & 49 \\
\hline Cluster 2 & 2.14 & 4.23 & 3.98 & 2.78 & 0.41 & 3.80 & 3.57 & 4.50 & 15 \\
\hline Cluster 3 & 0.57 & 3.01 & 1.99 & 2.18 & 0.14 & 2.68 & 2.30 & 1.15 & 10 \\
\hline Cluster 4 & 0.49 & 2.85 & 2.26 & 1.84 & 0.16 & 3.19 & 2.32 & 4.15 & 26 \\
\hline Cluster 1 & 0.92 & 3.45 & 2.12 & 2.25 & 0.19 & 3.36 & 3.04 & 6.47 & 34 \\
\hline Cluster 2 & 2.09 & 4.29 & 3.95 & 2.80 & 0.52 & 3.82 & 4.49 & 7.73 & 15 \\
\hline Cluster 3 & 2.14 & 4.23 & 3.98 & 2.78 & 0.41 & 3.80 & 3.57 & 4.50 & 15 \\
\hline Cluster 4 & 0.57 & 3.01 & 1.99 & 2.18 & 0.14 & 2.68 & 2.30 & 1.15 & 10 \\
\hline Cluster 5 & 0.49 & 2.85 & 2.26 & 1.84 & 0.16 & 3.19 & 2.32 & 4.15 & 26 \\
\hline Overall average & 1.16 & 3.51 & 2.75 & 2.31 & 0.27 & 3.40 & 2.93 & 5.26 & \\
\hline Range & $0-4$ & $1-5$ & $1-5$ & $1-3$ & $0-1$ & $1-5$ & $1-5$ & $0-10$ & \\
\hline
\end{tabular}


Annex 3: Allocation of Vote Intention Parties to Party Families

\begin{tabular}{|c|c|}
\hline Party Family & Parties \\
\hline \multicolumn{2}{|l|}{ UK } \\
\hline Far left & None \\
\hline Centre-Left & Labour, SNP, Plaid Cymru, Greens \\
\hline Centre & Liberal Democrats \\
\hline Centre-right & Conservative \\
\hline Right-wing Populist & UKIP \\
\hline \multicolumn{2}{|l|}{ France } \\
\hline Far left & Parti Communiste; Parti de Gauche de Jean-Luc Mélenchon \\
\hline Centre-Left & Parti Socialiste \\
\hline Centre & Europe Ecologie/Les Verts; Mouvement Démocrate - Modem \\
\hline Centre-right & Les Républicains \\
\hline Right-wing Populist & Front National \\
\hline \multicolumn{2}{|l|}{ Germany } \\
\hline Far left & Piraten \\
\hline Centre-Left & SPD; Bundnis 90/Die Grunen; Die Linke \\
\hline Centre & FDP \\
\hline Centre-right & CDU \\
\hline Right-wing Populist & AfD \\
\hline \multicolumn{2}{|l|}{ Sweden } \\
\hline Far left & Vänsterpartiet; Feministiskt Initiativ \\
\hline Centre-Left & Miljöpartiet, Socialdemokraterna \\
\hline Centre & Centerpartiet Liberalerna (tidigare Folkpartiet) \\
\hline Centre-right & Moderaterna, Kristdemokraterna \\
\hline Right-wing Populist & Sverigedemokraterna \\
\hline
\end{tabular}




\begin{tabular}{|l|l|}
\hline & \\
\hline Denmark & \\
\hline Far left & Radikale Venstre; Venstre \\
\hline Centre-Left & Socialdemokraterne; Socialistisk Folkeparti \\
\hline Centre & Liberal Alliance \\
\hline Centre-right & Det Konservative Folkeparti Kristendemokraterne, \\
\hline Right-wing Populist & Dansk Folkeparti \\
\hline & \\
\hline Finland & \\
\hline Far left & Piraattipuolue; Soumen Kommunistinen Puolue; Vasemmistoliitto \\
\hline Centre-Left & Sosialidemokraattinen Puolue; Vihreä liitto; Suomen Ruotsalainen \\
& Kansanpuolue \\
\hline Centre & Keskusta \\
\hline Centre-right & Kokoomus; Kristillisdemokraatit \\
\hline Right-wing Populist & Perussuomalaiset \\
\hline & \\
\hline Poland & \\
\hline Far left & None \\
\hline Centre-Left & Zjednoczona Lewica \\
\hline Centre & Nowoczesna \\
\hline Centre-right & Prawo i Sprawiedliwo; Platforma Obywatelska; Polskie Stronnictwo Ludowe \\
\hline Right-wing Populist & Kukiz'15 \\
\hline & \\
\hline Italy & \\
\hline Far left & Sinistra Italiana \\
\hline Centre-Left & Partito Democratico \\
\hline Centre & Movimento Cinque Stelle \\
\hline Centre-right & Forza Italia; Fratelli d'Italia \\
\hline Right-wing Populist & Lega Nord; \\
\hline & \\
\hline Spain & Unidos Podemos \\
\hline Far left & \\
\hline
\end{tabular}




\begin{tabular}{|l|l|}
\hline Centre-Left & Partido Socialista Obrero Español \\
\hline Centre & Ciudadanos-Partido de la Ciudadanía \\
\hline Centre-right & Partido Popular \\
\hline Right-wing Populist & None \\
\hline & \\
\hline Holland & \\
\hline Far left & SP \\
\hline Centre-Left & PvdA \\
\hline Centre & D66 \\
\hline Centre-right & VVD, CDA \\
\hline Right-wing Populist & PVV \\
\hline
\end{tabular}


Annex 4: Relationship between Party Family and Authoritarian Populist Status, by Country

Table A4.1: UK

\begin{tabular}{|l|c|c|c|}
\hline & \multicolumn{3}{|c|}{ AP tribe status } \\
\hline & $\begin{array}{c}\text { Not in an AP } \\
\text { Tribe }\end{array}$ & $\begin{array}{c}\text { Member of } \\
\text { Left AP tribe }\end{array}$ & $\begin{array}{c}\text { Member of } \\
\text { Right AP tribe }\end{array}$ \\
\hline Party Family & & & 0 \\
\hline Far Left & 0 & 0 & 8 \\
\hline Centre Left & 61 & 43 & 2 \\
\hline Centre & 12 & 5 & 67 \\
\hline Centre Right & 26 & 27 & 24 \\
\hline Right Wing Populist & 1 & 25 & 0 \\
\hline
\end{tabular}

Column percentages reported; data weighted by internal country weights

Table A4.2: France

\begin{tabular}{|l|c|c|}
\hline & \multicolumn{2}{|c|}{ AP tribe status } \\
\hline & $\begin{array}{c}\text { Not in an AP } \\
\text { Tribe }\end{array}$ & $\begin{array}{c}\text { Member of } \\
\text { Right AP tribe }\end{array}$ \\
\hline Party Family & & \\
\hline Far Left & 40 & 3 \\
\hline Centre Left & 37 & 12 \\
\hline Centre & 11 & 16 \\
\hline Centre Right & 2 & 39 \\
\hline Right Wing Populist & 10 & 30 \\
\hline
\end{tabular}

Column percentages reported; data weighted by internal country weights 
Table A4.3: Germany

\begin{tabular}{|l|c|c|}
\hline & \multicolumn{2}{|c|}{ AP tribe status } \\
\hline & $\begin{array}{c}\text { Not in an AP } \\
\text { Tribe }\end{array}$ & $\begin{array}{c}\text { Member of } \\
\text { Right AP tribe }\end{array}$ \\
\hline Party Family & & \\
\hline Far Left & 3 & 0 \\
\hline Centre Left & 58 & 16 \\
\hline Centre & 5 & 4 \\
\hline Centre Right & 28 & 17 \\
\hline Right Wing Populist & 7 & 63 \\
\hline
\end{tabular}

Column percentages reported; data weighted by internal country weights

\section{Table A4.4: Sweden}

\begin{tabular}{|l|c|c|}
\hline & \multicolumn{2}{|c|}{ AP tribe status } \\
\hline & $\begin{array}{c}\text { Not in an AP } \\
\text { Tribe }\end{array}$ & $\begin{array}{c}\text { Member of } \\
\text { Right AP tribe }\end{array}$ \\
\hline Party Family & & 1 \\
\hline Far Left & 19 & 11 \\
\hline Centre Left & 39 & 6 \\
\hline Centre & 13 & 30 \\
\hline Centre Right & 26 & 52 \\
\hline Right Wing Populist & 4 & 1 \\
\hline
\end{tabular}

Column percentages reported; data weighted by internal country weights 
Table A4.5: Denmark

\begin{tabular}{|l|c|c|}
\hline & \multicolumn{2}{|c|}{ AP tribe status } \\
\hline & $\begin{array}{c}\text { Not in an AP } \\
\text { Tribe }\end{array}$ & $\begin{array}{c}\text { Member of } \\
\text { Right AP tribe }\end{array}$ \\
\hline Party Family & & \\
\hline Far Left & 14 & 2 \\
\hline Centre Left & 65 & 14 \\
\hline Centre & 3 & 14 \\
\hline Centre Right & 10 & 41 \\
\hline Right Wing Populist & 8 & 29 \\
\hline
\end{tabular}

Column percentages reported; data weighted by internal country weights

Table A4.6: Finland

\begin{tabular}{|l|c|c|c|}
\hline & \multicolumn{3}{|c|}{ AP tribe status } \\
\hline & $\begin{array}{c}\text { Not in an AP } \\
\text { Tribe }\end{array}$ & $\begin{array}{c}\text { Member of } \\
\text { Left AP tribe }\end{array}$ & $\begin{array}{c}\text { Member of } \\
\text { Right AP tribe }\end{array}$ \\
\hline Party Family & 13 & 40 & 7 \\
\hline Far Left & 42 & 48 & 23 \\
\hline Centre Left & 12 & 8 & 24 \\
\hline Centre & 29 & 1 & 23 \\
\hline Centre Right & 4 & 3 & 23 \\
\hline Right Wing Populist & & & \\
\hline
\end{tabular}

Column percentages reported; data weighted by internal country weights 
Table A4.7: Poland

\begin{tabular}{|l|c|c|c|}
\hline & \multicolumn{3}{|c|}{ AP tribe status } \\
\hline & $\begin{array}{c}\text { Not in an AP } \\
\text { Tribe }\end{array}$ & $\begin{array}{c}\text { Member of } \\
\text { Left AP tribe }\end{array}$ & $\begin{array}{c}\text { Member of } \\
\text { Right AP tribe }\end{array}$ \\
\hline Party Family & & & 0 \\
\hline Far Left & 0 & 0 & 0 \\
\hline Centre Left & 14 & 3 & 2 \\
\hline Centre & 27 & 20 & 91 \\
\hline Centre Right & 50 & 54 & 7 \\
\hline Right Wing Populist & 9 & 23 & 0 \\
\hline
\end{tabular}

Column percentages reported; data weighted by internal country weights

Table A4.8: Italy

\begin{tabular}{|l|c|c|c|}
\hline & \multicolumn{3}{|c|}{ AP tribe status } \\
\hline & $\begin{array}{c}\text { Not in an AP } \\
\text { Tribe }\end{array}$ & $\begin{array}{c}\text { Member of } \\
\text { Left AP tribe }\end{array}$ & $\begin{array}{c}\text { Member of } \\
\text { Right AP tribe }\end{array}$ \\
\hline Party Family & & & 4 \\
\hline Far Left & 12 & 6 & 26 \\
\hline Centre Left & 32 & 3 & 45 \\
\hline Centre & 41 & 25 & 17 \\
\hline Centre Right & 12 & 40 & 8 \\
\hline Right Wing Populist & 3 & 26 & 4 \\
\hline
\end{tabular}

Column percentages reported; data weighted by internal country weights 
Table A4.9: Spain

\begin{tabular}{|l|c|c|}
\hline & \multicolumn{2}{|c|}{ AP tribe status } \\
\hline & $\begin{array}{c}\text { Not in an AP } \\
\text { Tribe }\end{array}$ & $\begin{array}{c}\text { Member of } \\
\text { Right AP tribe }\end{array}$ \\
\hline Party Family & & \\
\hline Far Left & 14 & 46 \\
\hline Centre Left & 20 & 51 \\
\hline Centre & 19 & 1 \\
\hline Centre Right & 47 & 1 \\
\hline Right Wing Populist & 0 & 0 \\
\hline
\end{tabular}

Column percentages reported; data weighted by internal country weights

Table A4.8: Holland

\begin{tabular}{|l|c|c|c|}
\hline & \multicolumn{3}{|c|}{ AP tribe status } \\
\hline & $\begin{array}{c}\text { Not in an AP } \\
\text { Tribe }\end{array}$ & $\begin{array}{c}\text { Member of } \\
\text { Left AP tribe }\end{array}$ & $\begin{array}{c}\text { Member of } \\
\text { Right AP tribe }\end{array}$ \\
\hline Party Family & & & 8 \\
\hline Far Left & 18 & 16 & 5 \\
\hline Centre Left & 21 & 15 & 9 \\
\hline Centre & 15 & 7 & 28 \\
\hline Centre Right & 35 & 24 & 50 \\
\hline Right Wing Populist & 11 & 38 & 8 \\
\hline
\end{tabular}

Column percentages reported; data weighted by internal country weights 
Annex 5: Pooled Ordered Logit Model of Party-Family Vote Intention in Ten European Countries

\begin{tabular}{|l|l|l|l|}
\hline & Coefficient & $\begin{array}{l}\text { Robust } \\
\text { Standard } \\
\text { Error }\end{array}$ & Probability \\
\hline Age & .00 & .00 & .27 \\
\hline Male/not & .20 & .11 & .06 \\
\hline Education & .05 & .05 & .34 \\
\hline Authoritarian Populist/not & 1.01 & .38 & .01 \\
\hline 'Not Home around here' scale & .49 & .06 & .00 \\
\hline Annual average GDP change 2006-15 & .46 & .45 & .07 \\
\hline Percent Population foreign born 2015 & .01 & .04 & .80 \\
\hline Cut 1 & .32 & .49 & \\
\hline Cut 2 & 2.19 & .49 & \\
\hline Cut 3 & 2.92 & .45 & \\
\hline Cut 4 & 4.61 & .45 & \\
\hline Pseudo R2 & .09 & & \\
\hline N & 6466 & & \\
\hline
\end{tabular}

Dependent variable is a 5-category ordered measure: 1=Far left; 2=Centre-left; 3=Centre;

4=Centre-right; 5=Right-wing Populist

Ordered logit with robust standard errors adjusted for 10 (country) clusters 